\title{
Differential effects of cigarette smoke on oxidative stress and proinflammatory cytokine release in primary human airway epithelial cells and in a variety of transformed alveolar epithelial cells
}

\author{
Aruna Kode, Se-Ran Yang and Irfan Rahman*
}

Address: Department of Environmental Medicine, Lung Biology and Disease Program, University of Rochester Medical Center, Rochester, NY, USA Email: Aruna Kode - Aruna_Kode@urmc.rochester.edu; Se-Ran Yang - Seran_Yang@urmc.rochester.edu; Irfan Rahman* - Irfan_Rahman@urmc.rochester.edu

* Corresponding author

Published: 24 October 2006

Respiratory Research 2006, 7:132 doi:10.1 |86/1465-992|-7-132

This article is available from: http://respiratory-research.com/content/7/I// 32

(c) 2006 Kode et al; licensee BioMed Central Ltd.

This is an Open Access article distributed under the terms of the Creative Commons Attribution License (http://creativecommons.org/licenses/by/2.0), which permits unrestricted use, distribution, and reproduction in any medium, provided the original work is properly cited.
Received: 19 July 2006

Accepted: 24 October 2006

\begin{abstract}
Background: Cigarette smoke mediated oxidative stress and inflammatory events in the airway and alveolar epithelium are important processes in the pathogenesis of smoking related pulmonary diseases. Previously, individual cell lines were used to assess the oxidative and proinflammatory effects of cigarette smoke with confounding results. In this study, a panel of human and rodent transformed epithelial cell lines were used to determine the effects of cigarette smoke extract (CSE) on oxidative stress markers, cell toxicity and proinflammatory cytokine release and compared the effects with that of primary human small airway epithelial cells (SAEC).

Methods: Primary human SAEC, transformed human (A549, HI299, H44I), and rodent (murine MLE-15, rat L2) alveolar epithelial cells were treated with different concentrations of CSE $(0.2-$ 10\%) ranging from $20 \mathrm{~min}$ to $24 \mathrm{hr}$. Cytotoxicity was assessed by lactate dehydrogenase release assay, trypan blue exclusion method and double staining with acridine orange and ethidium bromide. Glutathione concentration was measured by enzymatic recycling assay and 4-hydroxy-2nonenal levels by using lipid peroxidation assay kit. The levels of proinflammatory cytokines (e.g. IL-8 and IL-6) were measured by ELISA. Nuclear translocation of the transcription factor, NF-KB was assessed by immunocytochemistry and immunoblotting.
\end{abstract}

Results: Cigarette smoke extract dose-dependently depleted glutathione concentration, increased 4-hydroxy-2-nonenal (4-HNE) levels, and caused necrosis in the transformed cell lines as well as in SAEC. None of the transformed cell lines showed any significant release of cytokines in response to CSE. CSE, however, induced IL-8 and IL-6 release in primary cell lines in a dose-dependent manner, which was associated with the nuclear translocation of NF-KB in SAEC.

Conclusion: This study suggests that primary, but not transformed, lung epithelial cells are an appropriate model to study the inflammatory mechanisms in response to cigarette smoke. 


\section{Background}

Cigarette smoke, a complex admixture of more than 4700 chemical compounds and oxidants [1], is an important etiological factor in the development of chronic obstructive pulmonary disease (COPD). It contains $10^{14}-10^{16}$ free radicals/puff, which include reactive aldehydes, quinones and benzo(a)pyrene [2]. Many of these are relatively long lived, such as tar-semiquinone, which can also generate hydroxyl radicals $(\bullet \mathrm{OH})$ and hydrogen peroxide $\left(\mathrm{H}_{2} \mathrm{O}_{2}\right)$ by Fenton reaction in presence of free iron. These agents induce an oxidative burden by disturbing the oxidant:antioxidant balance and could lead to cellular damage in the lungs. Oxidative stress caused by cigarette smoking can result in destruction of the alveolar wall, leading to airway enlargement. Moreover, increased oxidative stress can trigger proinflammatory cytokines, which are increased in the lungs of smokers and patients with COPD $[3,4]$.

The airway/airspace epithelium is the primary target for any inhaled environmental agents and plays a critical role in the release of pro-inflammatory mediators. It is also involved in the progression of tissue injury during inflammatory conditions, implicating the role of airway/airspace epithelium in the pathogenesis of inflammatory airway diseases such as COPD. Previous in vivo findings have supported the above, wherein; cigarette smoke was shown to induce proinflammatory cytokine release in smokers and in rodent lungs $[5,6]$. However, the precise molecular mechanism as how cigarette smoke generates signals for proinflammatory cytokine release, particularly in airway or alveolar epithelium is not yet clearly understood.

Earlier, we have demonstrated the ability of cigarette smoke extract (CSE) to induce oxidative stress in transformed human alveolar epithelial cells (A549), which could not be correlated to the release of any proinflammatory cytokines $[7,9]$. A549 is the most widely used cell line and is well criticized in the literature [10]. In this study, we investigated whether cigarette smoke can trigger proinflammatory cytokine release in any other alveolar epithelial cell lines derived from either human or rodents. To test our hypothesis, we used a panel of human and rodent alveolar epithelial cell lines, such as human lung cancer cells (H1299), human lung epithelial cells (H441), murine type II epithelial cells (MLE-15), and rat lung epithelial cells (L2) in addition to human adenocarcinoma cells (A549). Another aim of this study was to develop an in vitro cell culture model for understanding the mechanisms of proinflammatory effects of cigarette smoke exposure. To this extent, we studied the effect of CSE on oxidative stress (reduced glutathione and 4-hydroxy-2nonenal), cell toxicity (lactate dehydrogenase release, apoptosis and necrosis) and proinflammatory cytokine release (IL-6 and IL-8) in various transformed epithelial cell lines and in primary human small airway epithelial cells.

\section{Materials and methods}

All biochemicals were of analytical grade and purchased from Sigma Chemical Co (St. Louis, MO) unless otherwise stated.

\section{Materials}

Penicillin, streptomycin and culture media (DMEM, RPMI 1640, F12K) were procured from Life technologies (Gaithersburg, MD, USA). Fetal bovine serum (FBS) was obtained from HyClone Laboratories (Logan, UT, USA). Rabbit polyclonal anti NF-אB Rel/p65 antibody (sc-372) was purchased from Santa Cruz Biotechnology Inc., (Santa Cruz, CA, USA).

\section{Cell culture}

Five different alveolar epithelial type II cell lines were used for this study along with the primary human small airway epithelial cells (SAEC). The sources of various cell lines were as follows: the human adenocarcinoma epithelial cells (A549) derived from lungs of adenocarcinoma patient, human lung epithelial cells from papillary adenocarcinoma patient (H441), human lung cancer cells from cancer patient (H1299), and rat lung epithelial cells (L2) were obtained from American Type Cell Collection (ATCC), Manassas, VA, USA. Murine type II epithelial cells (MLE-15) were derived from immortalized lung tumors of transgenic mice containing the simian virus 40 large $\mathrm{T}$ antigen under the transcriptional control of the regulatory sequences derived from the human surfactant protein (SP)-C promoter region $[11,12]$. Cells were grown in culture media (A549 and H1299: Dulbecco's modified Eagle medium, H441: RPMI 1640 medium, MLE-15: DMEM/F12K medium and L2: F12K medium) supplemented with $10 \%$ FBS, $2 \mathrm{mM}$ L-glutamine, $100 \mathrm{IU} / \mathrm{ml}$ penicillin, $100 \mu \mathrm{g} / \mathrm{ml}$ streptomycin at $37^{\circ} \mathrm{C}$ in a humidified atmosphere containing $5 \% \mathrm{CO}_{2}$.

SAEC derived from a single healthy non-smoker, and the basal media (SAGM) including all the growth supplements were purchased from Clonetics (San Diego, CA, USA). Cells were cultured according to the supplier's instructions. Passage number was kept to less than seven passages from original stocks. SAEC were maintained in SAGM supplemented with $52 \mu \mathrm{g} / \mathrm{ml}$ bovine pituitary extract, $0.5 \mathrm{ng} / \mathrm{ml}$ human recombinant epidermal growth factor (EGF), $0.5 \mu \mathrm{g} / \mathrm{ml}$ epinephrine, $10 \mu \mathrm{g} / \mathrm{ml}$ transferrin, $5 \mu \mathrm{g} / \mathrm{ml}$ insulin, $0.1 \mathrm{ng} / \mathrm{ml}$ retinoic acid (RA), $6.5 \mathrm{ng} / \mathrm{ml}$ triiodothyronine, $50 \mu \mathrm{g} / \mathrm{ml}$ Gentamicin/Amphotericin-B (GA-1000), and $50 \mu \mathrm{g} / \mathrm{ml}$ fatty acid-free bovine serum albumin (BSA). Polymyxin B sulfate, an endotoxin binding agent $(10 \mu \mathrm{g} / \mathrm{ml})$, was also included in the media to prevent lipopolysaccharide contamination [13]. 


\section{Preparation of aqueous cigarette smoke extract} Research grade cigarettes (1R3F) were obtained from the Kentucky Tobacco Research and Development Center at the University of Kentucky, Lexington, KY, USA. The composition of 1R3F research grade cigarettes was: total particulate matter: $17.1 \mathrm{mg} /$ cigarette, tar: $15 \mathrm{mg} /$ cigarette and nicotine: $1.16 \mathrm{mg} /$ cigarette. Cigarette smoke extract (10\%) was prepared by bubbling smoke from one cigarette into $10 \mathrm{ml}$ of culture media supplemented with $1 \%$ FBS at a rate of one cigarette/minute as described previously [9,13], using a modification of the method described earlier by Carp and Janoff [14]. The pH of the CSE was adjusted to 7.4, and was sterile filtered through a $0.45 \mu \mathrm{m}$ filter (25 mm Acrodisc; Pall Corporation, Ann Arbor, MI). Cigarette smoke extract preparation was standardized by measuring the absorbance (OD $0.74 \pm$ 0.05 ) at a wavelength of $320 \mathrm{~nm}$. The pattern of absorbance (spectrogram) observed at $\lambda_{320}$ showed a very little variation between different preparations of CSE. Cigarette smoke extract was freshly prepared for each experiment and diluted with culture media supplemented with $1 \%$ FBS immediately before use. Control medium was prepared by bubbling air through $10 \mathrm{ml}$ of culture media supplemented with $1 \%$ FBS, and the $\mathrm{pH}$ was adjusted to 7.4, and sterile filtered as described above.

\section{Cell treatments}

Epithelial cells (H1299, A549, H441, MLE-15 and L2) were seeded at a density of 1.5 million cells in 6-well plates containing culture media supplemented with $10 \%$ FBS in a final volume of $2 \mathrm{ml}$. The cells were grown to approximately $80-90 \%$ confluency, then changed to $1 \%$ FBS during the treatment. All treatments were performed in duplicate. The cells were treated with CSE (1.0-10\%) for $24 \mathrm{hr}$ at $37^{\circ} \mathrm{C}$ in a humidified atmosphere containing $5 \% \mathrm{CO}_{2} .10 \mathrm{ng} / \mathrm{ml}$ tumor necrosis factor- $\alpha$ (TNF- $\alpha$ ), was used as a positive control in selected experiments [15]. After 24 hr treatment, cell supernatants were collected for LDH release and proinflammatory cytokines (interleukin8 and interleukin-6) assays. Cell lysates were prepared for GSH and 4-HNE assays. Similarly, the epithelial cells were grown in 8-well chamber slides and treated with CSE (1.0-10\%) for $24 \mathrm{hr}$ and stained with a solution comprising of acridine orange and ethidium bromide dyes for apoptotic and necrotic studies.

Human SAEC were seeded in 12-well plates containing SAGM. After reaching $80 \%$ confluency, the cells were treated with either TNF- $\alpha(10 \mathrm{ng} / \mathrm{ml})$ or CSE $(0.2-1.0 \%)$; as higher doses $(>1.0 \%)$ were cytotoxic to the cells. After the incubation period, the culture media was collected for LDH release and proinflammatory cytokines (IL-8 and IL6) assay. Cell lysates were prepared for GSH, 4-HNE assays and western blotting for p65 protein. Primary cells were also grown in 8-well chamber slides, treated as described above, and were fixed with 4\% paraformaldehyde for the detection of NF- $\kappa$ B nuclear translocation.

\section{Cytotoxicity assay}

Cell toxicity was assessed by three separate methods: LDH release assay, trypan blue exclusion method and double staining with acridine orange and ethidium bromide.

\section{Lactate dehydrogenase assay}

LDH release, an indicator of membrane integrity and viability of alveolar epithelial cells, was measured in various treated samples, and compared with control (untreated) cultures using a commercially available LDH cytotoxicity assay kit (Roche Diagnostics, Indianapolis, USA). Following treatments, the culture medium was collected and centrifuged at $5000 \mathrm{rpm}$ for $5 \mathrm{~min}$ prior to analysis. Assay was performed according to the manufacturer's instructions. LDH release was quantified by measuring the absorbance at $490 \mathrm{~nm}$ using a microplate reader (Bio-Rad, Hercules, CA, USA). A 100\% lysis control was prepared by adding $1 \%$ Triton-X-100 to control cell pellet to release all LDH. The absorbance value obtained was used for calculating percentage cytotoxicity.

\section{Trypan blue exclusion assay}

After $24 \mathrm{hr}$ incubation, the culture medium was removed and replaced by $0.1 \%$ trypan blue solution in $\mathrm{Ca}^{2+} / \mathrm{Mg}^{2+}$ free phosphate buffered saline (PBS) for $3 \mathrm{~min}$ at room temperature. The cells stained blue were considered nonviable cells, whereas the cells that excluded the stain were considered viable.

\section{Assay of apoptosis and necrosis}

Morphological evidence of apoptosis and necrosis was obtained by means of acridine orange and ethidium bromide staining as described previously $[16,17]$. In brief, after treatment, cells in 8-well chamber slides were stained with acridine orange $(4 \mu \mathrm{g} / \mathrm{ml})$ and ethidium bromide $(4$ $\mu \mathrm{g} / \mathrm{ml}$ ). Cells were examined by fluorescence microscopy (Olympus BX51 microscope, New Hyde Park, NY, USA), and photographed using a SPOT camera with SPOT RT software (Olympus). Acridine orange permeates throughout the cells and renders the nuclei green. Ethidium bromide is taken up by the cells only when cytoplasmic membrane integrity is lost, and stains the nuclei red. Viable (normal, green nuclei), early apoptotic (condensed, green nuclei), late apoptotic (condensed, red nuclei) and necrotic (normal, red nuclei) cells were quantified by counting a minimum of 100 cells in total in three independent experiments.

\section{Measurement of intracellular 4-hydroxy-2-nonenal levels} 4-HNE levels were measured in cell lysates by using lipid peroxidation assay kit (Calbiochem, San Diego, CA, USA). After the treatment period, cells were rinsed twice 
with ice-cold PBS and scraped off using cell scrapers (Sarsdet Inc. Newton, NC, USA). The pellet was resuspended in $200 \mu \mathrm{l}$ of $20 \mathrm{mM}$ Tris- $\mathrm{HCl}, \mathrm{pH} 7.4$, containing $5 \mathrm{mM}$ butylated hydroxytoluene, and kept frozen at $70^{\circ} \mathrm{C}$ until assayed. To each sample, $650 \mu \mathrm{l}$ of N-methyl2-phenylindole and $150 \mu \mathrm{l}$ of $15.4 \mathrm{M}$ methanesulfonic acid were added. The reaction mixture was vortexed and incubated at $45^{\circ} \mathrm{C}$ for $60 \mathrm{~min}$. After centrifugation at $15000 \mathrm{~g}$ for $10 \mathrm{~min}$, the absorbance of the supernatant was determined at $586 \mathrm{~nm}$. The levels of 4-HNE were determined from standard calibration curve constructed using 4-HNE diethylacetal in methanesulfonic acid. The values were expressed as $\mu \mathrm{mol} 4-\mathrm{HNE} / \mathrm{mg}$ protein.

\section{Measurement of intracellular glutathione levels}

Intracellular GSH levels in the cell extracts were measured by the 5,5'-dithiobis-2-nitrobenzoic acid DTNB-GSSG reductase recycling method described by Tietze [18] with slight modifications $[8,19,20]$. In brief, the cells were rinsed twice with ice-cold PBS, scraped off from the 6 well plate, suspended into $500 \mu \mathrm{l}$ of ice-cold extraction buffer (0.1\% Triton X-100 and $0.6 \%$ sulfosalicylic acid prepared in $0.1 \mathrm{M}$ phosphate buffer with $5 \mathrm{mM}$ EDTA, $\mathrm{pH}$ 7.5). The cells were vortexed for 20 seconds, followed by sonication (30 seconds) and centrifugation $(2500 \mathrm{rpm}$ for $5 \mathrm{~min}$ at $4{ }^{\circ} \mathrm{C}$ ). Twenty microlitres of the supernatant was added to $120 \mu \mathrm{l}$ of $0.1 \mathrm{M}$ phosphate buffer, $5 \mathrm{mM}$ EDTA, pH 7.5, containing $100 \mu \mathrm{l}$ of $5 \mathrm{mM}$ DTNB and 0.5 units of glutathione reductase. Finally $60 \mu \mathrm{l}$ of $2.4 \mathrm{mM} \mathrm{NADPH}$ was added and the rate of change in absorbance was measured for $1 \mathrm{~min}$ at $410 \mathrm{~nm}$ using a microplate reader (Bio-Rad, Hercules, CA, USA).

\section{Protein assay}

Protein levels were measured in the cell lysate supernatants in all samples using BCA kit (Pierce, Rockford, IL). Protein standards were obtained by diluting a stock solution of BSA. Linear regression was used to determine the actual protein concentration of each sample.

\section{Proinflammatory cytokine assay}

After treatment period, supernatants were removed and stored at $-70^{\circ} \mathrm{C}$. Pro-inflammatory cytokine (IL-8 and IL6) levels were measured using an ELISA employing a biotin-streptavidin-peroxidase detection system with the respective duo antibody kits (R\&D Systems) according to the manufacturer's instructions. Each sample was assayed in triplicate and the values were expressed as mean of three experiments.

\section{Immunocytochemical analysis of NF-KB ReIA/p65 localization}

Activation of NF- $\kappa \mathrm{B}$ in SAEC was assessed by immunocytochemical localization of RelA/p65 subunit of NF- $\mathrm{kB}$. SAEC were seeded at 5000 cells/well in 8-well glass cham- ber slides and cultured overnight in SAGM at $37^{\circ} \mathrm{C}$. Cells were then treated with CSE $(1.0 \%)$ and TNF- $\alpha(10 \mathrm{ng} / \mathrm{ml})$ as a positive control for $20 \mathrm{~min}$. At the end of incubation, the cells were washed twice in PBS and fixed in 4\% paraformaldehyde for $10 \mathrm{~min}$ at room temperature. The cells were permeabilized with $0.1 \%$ Triton X-100. The wash step was repeated and the cells were blocked with $10 \%$ normal goat serum for $1 \mathrm{hr}$. The cells were then incubated overnight in humidified chamber at $4^{\circ} \mathrm{C}$, with rabbit polyclonal antibodies directed against the RelA/p65 subunit of NF- $\kappa \mathrm{B}$ (Santa Cruz Biotechnology, USA), diluted at $1: 200$ in $1 \%$ goat serum in PBS. Furthermore, the cells were washed with PBS and incubated with FITC-labeled anti-rabbit IgG diluted 1:200 in 1\% goat serum for $1 \mathrm{hr}$ at room temperature in dark. After rinsing with PBS, the coverslips were mounted onto the slides and viewed under fluorescence microscope. Nuclear translocation of RelA/ p65 was interpreted as a positive result from the fluorescence obtained.

\section{Western blot analysis for NF-KB ReIA/p65}

Primary human SAEC were exposed to different concentrations of CSE (0.5 and $1.0 \%)$ for $1 \mathrm{hr}$. After treatment, the cells were washed with ice-cold PBS and resuspended in buffer A (10 mM HEPES, pH 7.9, $10 \mathrm{mM} \mathrm{KCl,} 0.1 \mathrm{mM}$ EDTA, $0.1 \mathrm{mM}$ EGTA, $1 \mathrm{mM}$ DTT, and $0.5 \mathrm{mM}$ PMSF). After 15 min of incubation, Nonidet P-40 was added and the samples were centrifuged to collect the supernatant containing cytosolic proteins. The pelleted nuclei were resuspended in buffer $\mathrm{B}$ (20 mM HEPES, pH 7.9, $0.4 \mathrm{M}$ $\mathrm{NaCl}, 1 \mathrm{mM}$ EDTA, $1 \mathrm{mM}$ EGTA, $1 \mathrm{mM}$ DTT, and $1 \mathrm{mM}$ PMSF) and kept on ice. After $30 \mathrm{~min}$ of incubation, the cell lysates were centrifuged, and supernatants containing the nuclear proteins were collected. Twenty $\mu \mathrm{g}$ of isolated nuclear protein from each group was analyzed by SDSPAGE and transferred onto nitrocellulose membrane (Amersham, Arlington Heights, IL, USA) using electroblotting technique. The nitrocellulose membrane was blocked with $10 \%$ nonfat dry milk for $1 \mathrm{hr}$ at room temperature, and subsequently incubated with rabbit polyclonal NF- $\kappa$ B RelA/p65 (1:1000) in 5\% nonfat dry milk overnight at $4{ }^{\circ} \mathrm{C}$. After three washing steps of $15 \mathrm{~min}$ each, NF-кB RelA/p65 protein levels were detected using goat anti-rabbit antibody $(1: 20,000)$ linked to horseradish peroxidase (Dako, Santa Barbara, CA, USA), and bound complexes were detected using an enhanced chemiluminescence method.

\section{Statistical analysis}

Statistical analysis of significance was calculated using one-way Analysis of Variance (ANOVA) followed by Tukey's post-hoc test for multigroup comparisons using STATVIEW and Sigma plot statistical packages. The results were presented as the mean \pm SEM of three independent experiments. ${ }^{*} \mathrm{p}<0.05,{ }^{\# / * *} \mathrm{p}<0.01$, and $\$ / * * * \mathrm{p}<0.001$. 


\begin{abstract}
Results
Cigarette smoke extract differentially induced cytotoxicity and reduced cell viability in a variety of alveolar epithelial cells and in primary human small airway epithelial cells

CSE differentially induced cell death in a concentrationdependent manner in various epithelial cell lines measured by LDH release assay (Figure 1A) and trypan blue exclusion assays (\% cell viability at 5.0\% CSE in H1299: $70 \pm 3.9 \%$; A549: $61 \pm 5.4 \% ;$ H441: $39 \pm 2.1 \%$; $2: 30 \pm$ $1.4 \%$, and MLE-15: $17 \pm 2.7 \%$ versus control 100\%, $\mathrm{n}=3$, $\mathrm{p}<0.001)$. Among the cell lines studied, murine epithelial cells (MLE-15) were most sensitive to CSE followed by rat lung epithelial cells (L2). Among the human lung epithelial cells, H441 were most sensitive when compared with H1299 and A549. Furthermore, our results revealed that H1299 cells were most resistant among the five cell lines studied. On the whole, the sensitivity to CSE was in the order MLE15 > L2 > H441 > A549 > H1299. In case of SAEC, CSE dose-dependently induced cytotoxicity as assayed by LDH release (Figure 1B) and trypan blue exclusion assay (\% cell viability at $0.2 \%$ CSE: $91 \pm 3.2 \% ; 0.5 \%$ CSE: $85 \pm 4.2 \% ; 1.0 \%$ CSE: $70 \pm 3.5 ; 2.5 \%$ CSE: $30 \pm 2.1$ and 5\% CSE: $11 \pm 2.5$ versus control $100 \%, \mathrm{n}=3, \mathrm{p}<$ $0.001)$. Cigarette smoke extract at concentrations above $1.0 \%$ was cytotoxic to SAEC.
\end{abstract}

\section{Cigarette smoke extract dose-dependently induced necrosis but not apoptosis in alveolar epithelial cells as well as in primary human small airway epithelial cells}

To assess the degree of necrosis and apoptosis induced by CSE in various epithelial cell lines, the cells were double stained with acridine orange and ethidium bromide and the staining was observed under a fluorescent microscope. CSE induced necrosis in a dose- dependent manner in all the transformed epithelial cells as well as in human primary SAEC. The percentage of necrosis varied among the transformed epithelial cell lines at a given concentration of CSE. For example, necrosis caused by 5\% CSE in various epithelial cell lines was as follows: H1299: $22 \pm 3.6 \%$; A549: $27 \pm 1.5 \%$; H441: $40 \pm 5.8 \%$; 2 : $69 \pm 4.3 \%$; and MLE-15: $76 \pm 5.2 \% ; n=3$ (Figures 2, 3, 4, 5, 6, 7). CSE did not cause a significant degree of apoptosis in any of these epithelial cell lines.

\section{Cigarette smoke extract dose-dependently increased lipid peroxidation in alveolar epithelial cells and in primary human small airway epithelial cells}

CSE dose-dependently increased the levels of 4-hydroxy2-nonenal in all the five epithelial cell lines as well as in SAEC. However, the basal levels varied from one cell line to another, which were in the order of MLE15 > L2 > H441 > A549 > H1299 > SAEC. The levels of 4-hydroxy-2-nonenal levels correlated with degree of cytotoxicity induced by CSE in these cell lines (Figures $8 \mathrm{~A}$ and $8 \mathrm{~B}$ ).
Cigarette smoke extract decreased intracellular glutathione levels in various alveolar epithelial cells as well as in primary human small airway epithelial cells

Glutathione is involved in various biological events including redox signaling in the lungs. CSE decreased the levels of GSH in all the five cell lines studied in a dosedependent manner (Figure 9A). CSE mediated GSH depletion was not associated with increased glutathione disulfide (GSSG) levels in A549 cells [8]. Interestingly, the baseline levels of GSH were varied based on their sensitivity to CSE amongst the different cell lines studied. CSE dose-dependently decreased the levels of GSH in SAEC at $4 \mathrm{hr}$, whereas the levels were increased dose-dependently at $24 \mathrm{hr}$ (Figure 9B).

\section{Differential effects of cigarette smoke extract on proinflammatory cytokine release in transformed epithelial cells and in primary human small airway epithelial cells}

Previously, we have shown that CSE treatment had no effect on A549 cells in terms of release of pro-inflammatory cytokines (IL-8) in A549 cells [9]. In this study, we investigated the pro-inflammatory effect of CSE in a variety of human as well as rodent alveolar epithelial cells (H1299, H441, MLE-15 and L2 in addition to A549) by using various concentrations of CSE (1.0-10\%), and TNF$\alpha$ as a positive control $(10 \mathrm{ng} / \mathrm{ml})$. Treatment with CSE showed insignificant proinflammatory cytokine (IL-8 and IL-6) release at $24 \mathrm{hr}$. However, TNF- $\alpha(10 \mathrm{ng} / \mathrm{ml})$ significantly increased pro-inflammatory cytokine (IL-8 and IL6) release at $24 \mathrm{hr}$ (Table 1). In order to study whether whole cigarette smoke or direct cigarette smoke exposure to cells can induce pro-inflammatory cytokine release, we exposed A549 cells to mainstream smoke (10 $\mu \mathrm{g}$ of total particulate matter, TPM $/ \mathrm{m}^{3}$ ) using a Baumgartner-Jaeger CSM2082i cigarette smoking machine [21] (CH Technologies, Westwood, NJ, USA), for $1 \mathrm{hr}$ and then incubated without exposure for further 3, 6 and $24 \mathrm{hr}$ as direct cigarette smoke exposure for longer than a few hours is cytotoxic. Proinflammatory cytokine (IL-8 and IL-6) release was measured in various supernatants. IL- 8 release was not observed in A549 cells in response to whole cigarette smoke exposure ( $3 \mathrm{hr}: 527 \pm 35 ; 6 \mathrm{hr}: 519 \pm 41 ; 24$ hr: 471 \pm 29 versus control $510 \pm 31 \mathrm{pg} / \mathrm{ml}, \mathrm{n}=3$ ). This suggested that transformed lung epithelial cells do not produce proinflammatory cytokines in response to either CSE or whole smoke direct exposure. Interestingly, CSE caused release of proinflammatory cytokines (IL-8 and IL-6) in SAEC (Table 2). CSE also induced IL-8 and IL-6 release from normal human bronchial epithelial cells (data not shown). 

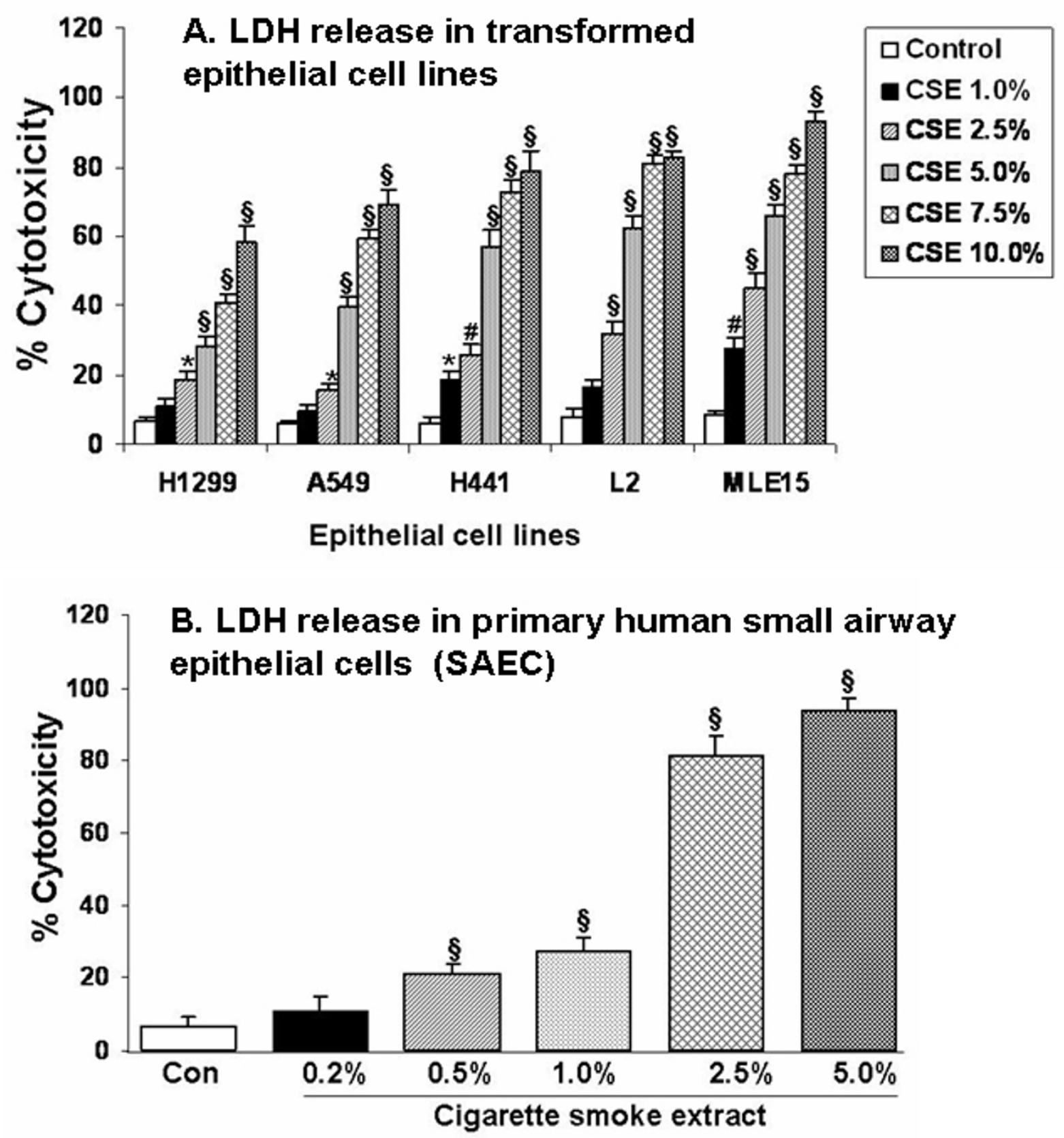

Figure I

Cigarette smoke extract differentially caused cytotoxicity in a variety of alveolar epithelial cells and in primary human small airway epithelial cells. A. Various alveolar epithelial cells such as human lung cancer cells (HI299), human adenocarcinoma cells (A549), human lung epithelial cell from papillary adenocarcinoma patient (H44I), rat lung epithelial cells (L2), and murine type II epithelial cells (MLE-I5) were exposed to different concentrations of cigarette smoke (IR3F) extract ( $1.0-10.0 \%)$ for $24 \mathrm{hr}$, and \% cytotoxicity induced was measured as lactate dehydrogenase release. CSE differentially induced cytotoxicity in concentration dependent manner in all the five epithelial cell lines. Amongst the five cell lines studied, HI299 cells were most resistant and MLE I 5 cells were the least resistant. B. Primary human small airway epithelial cells (SAEC) were exposed to different concentrations of cigarette smoke (IR3F) extract (0.2-5.0\%) for $24 \mathrm{hr}$ and percentage (\%) cytotoxicity induced was measured as LDH release. CSE dose-dependently induced LDH release in SAEC. Data represent mean \pm SEM of 3 experiments. ${ }^{*} p<0.05,{ }^{*} p<0.01$, and ${ } p<0.001$ compared to control group. CSE: cigarette smoke extract. 


\section{Human lung cancer cells (H1299)}
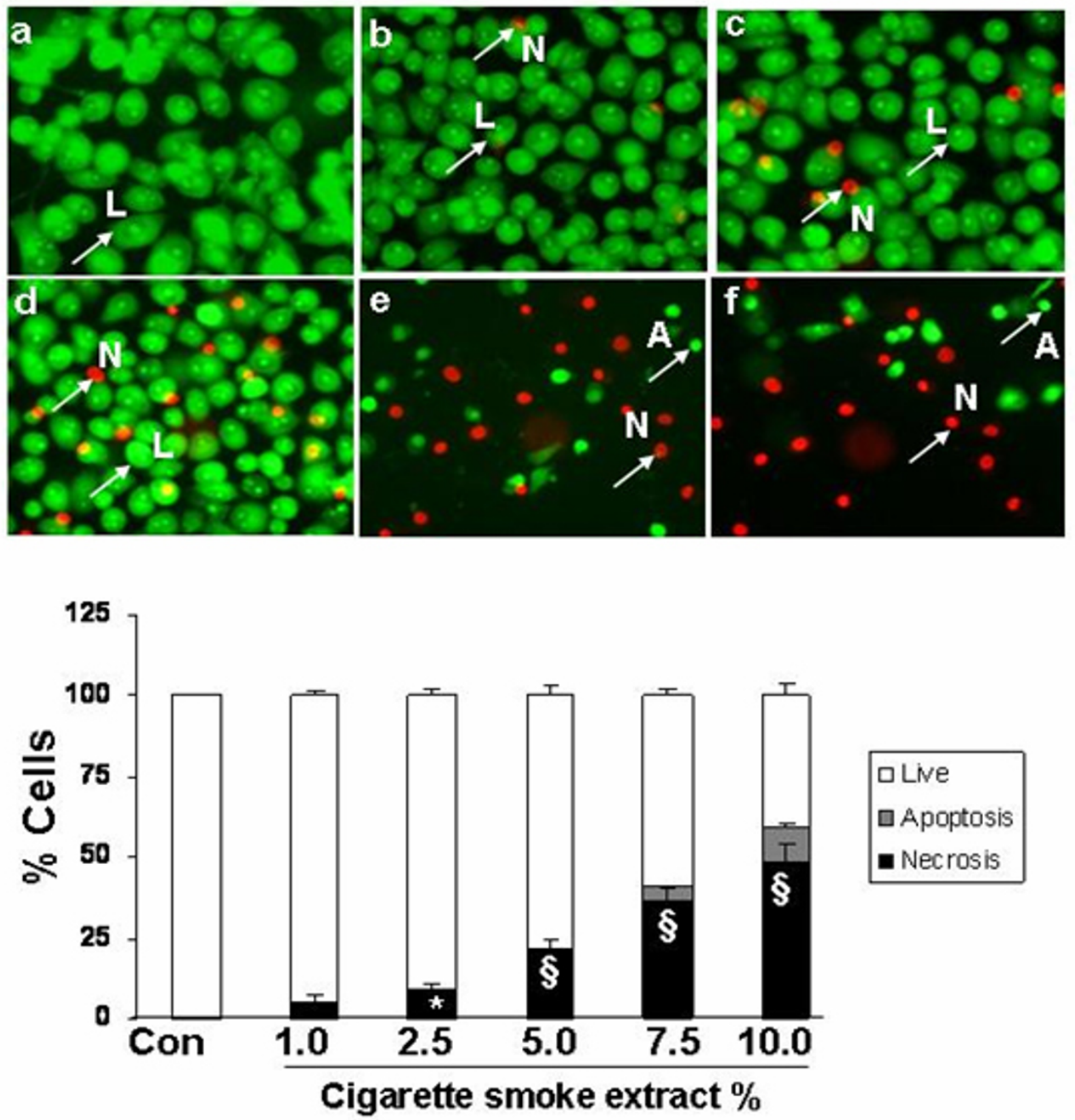

Figure 2

Cigarette smoke extract caused necrosis with no or little evidence of apoptosis in human lung cancer cells (HI 299). Human lung cancer cells (HI299) were treated with media alone (control) and various concentrations of CSE; a) control, b) CSE (I.0\%), c) CSE (2.5\%), d) CSE (5.0\%), e) CSE (7.5\%), f) CSE (10\%) for 24 hr. The cells were stained with ethidium bromide and acridine orange and observed under fluorescence microscopy. Living cells had normal shaped nuclei with green chromatin. Early apoptotic cells have shrunken green nuclei with chromatin condensation, whereas necrotic or late apoptotic cells had normal/condensed nuclei that were brightly stained with ethidium bromide and appeared red. Percentage of viable (white bars), apoptotic (grey bars) and necrotic/late apoptotic (black bars) determined by counting as described in Materials and Methods. Results are mean of 3 experiments $\pm S E M$. ${ }^{*} p<0.05$, and $\S_{p}<0.00$ I compared with control group. $L=$ Live; A = Apoptosis; $N$ = Necrosis. 


\section{Human adenocarcinoma epithelial cells (A549)}
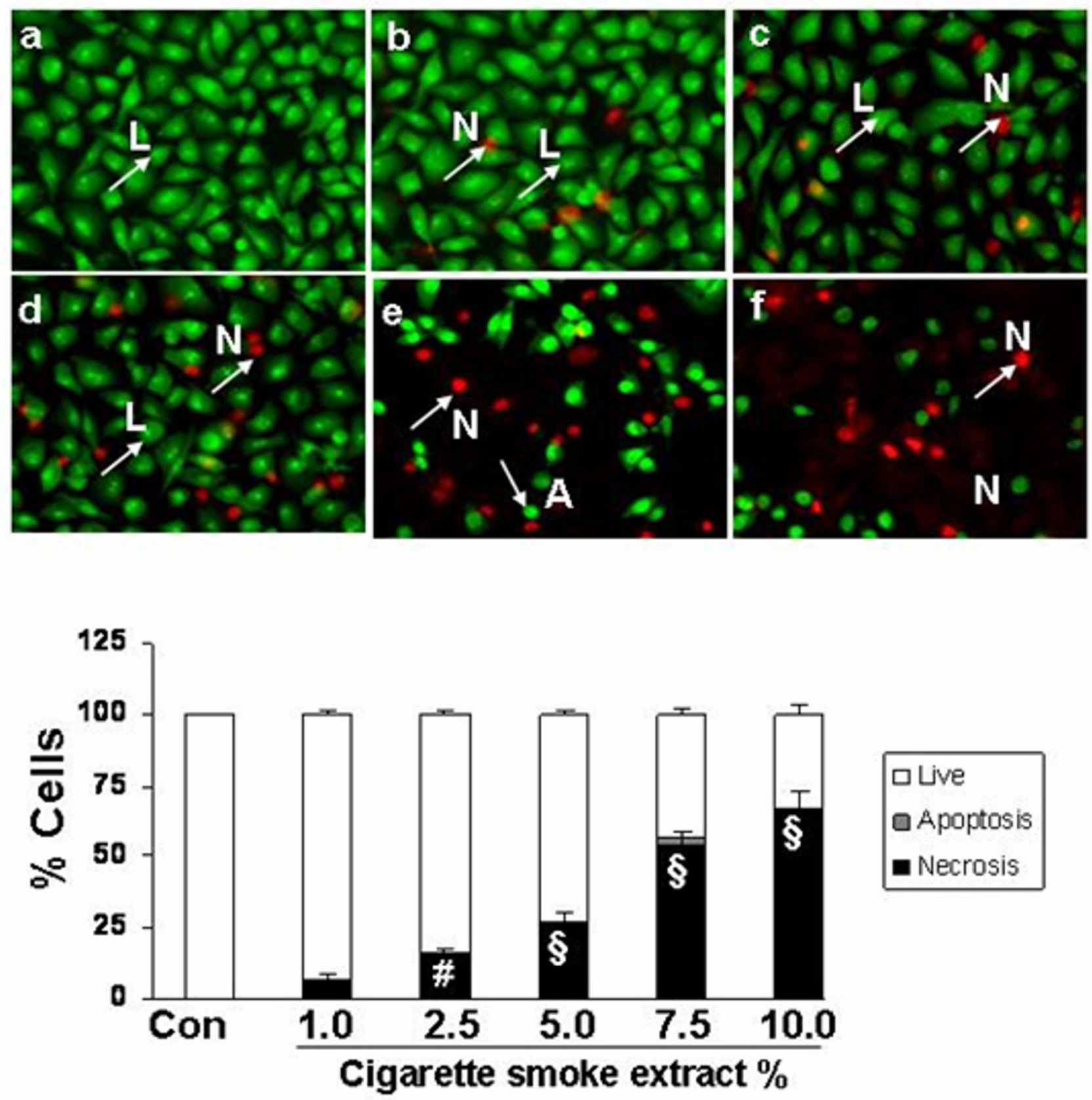

Figure 3

Cigarette smoke extract induced necrosis with no or little evidence of apoptosis in human adenocarcinoma cells (A549). Human adenocarcinoma cells (A549) were treated with media alone (control) and various concentrations of CSE; a) control, b) CSE (I.0\%), c) CSE (2.5\%), d) CSE (5.0\%), e) CSE (7.5\%), f) CSE (I0\%) for $24 \mathrm{hr}$. Results are mean of 3 experiments \pm SEM. ${ }^{*} p<0.01$, and $\oint_{p}<0.001$ compared with control group. $L=$ Live; $A=$ Apoptosis; $N=N$ Necrosis. 


\section{Human papillary adenocarcinoma cells (H441)}
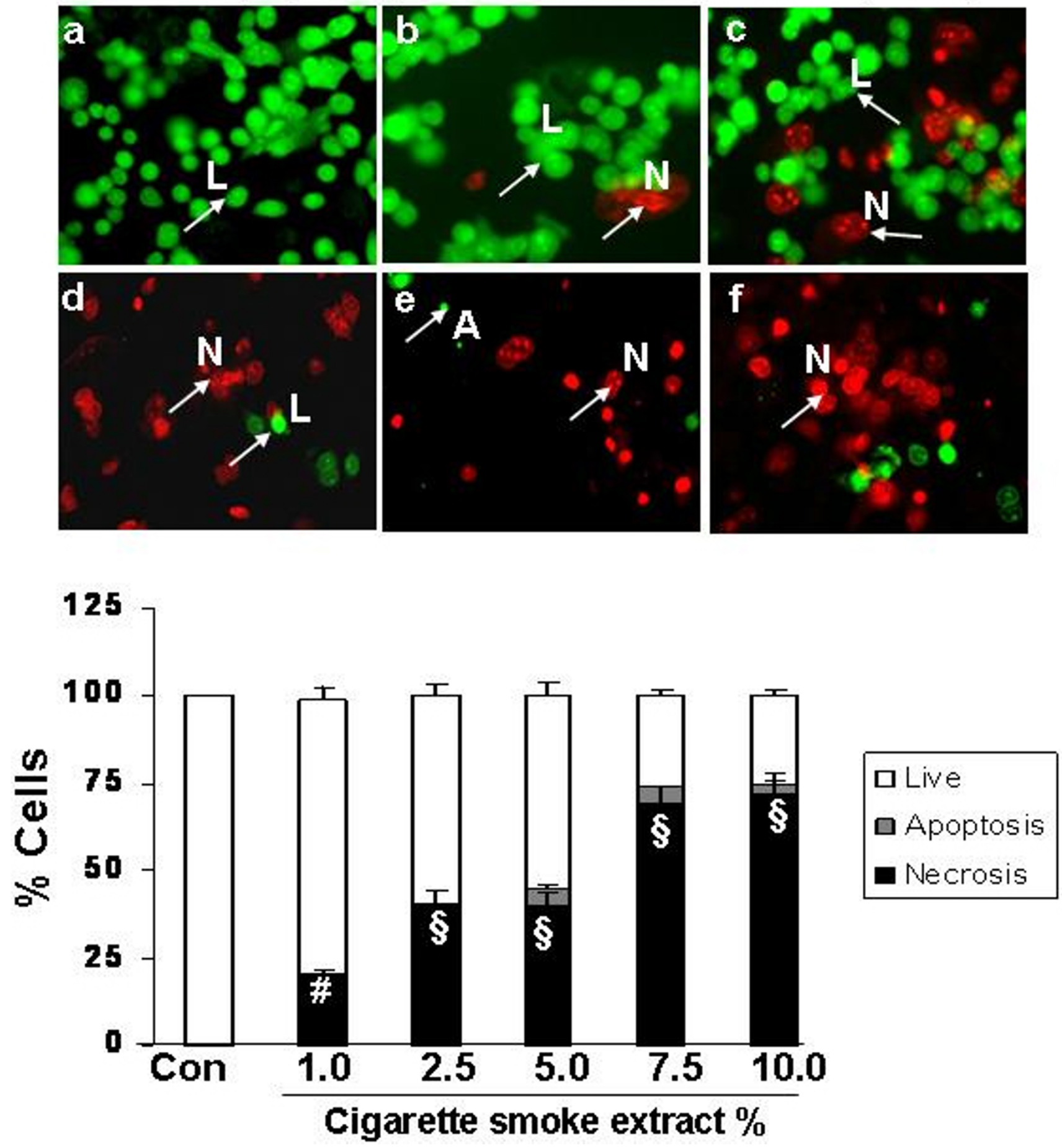

Figure 4

Cigarette smoke extract caused necrosis with no or little evidence of apoptosis in human lung epithelial cell from papillary adenocarcinoma patient ( $\mathrm{H44}$ I). Human lung epithelial cell from papillary adenocarcinoma patient $(\mathrm{H} 44 \mathrm{I})$ were treated with media alone (control) and various concentrations of CSE; a) control, b) CSE (I.0\%), c) CSE (2.5\%), d) CSE (5.0\%), e) CSE (7.5\%), f) CSE (I0\%) for $24 \mathrm{hr}$. Results are mean of 3 experiments \pm SEM. ${ }^{\prime} p<0.01$, and $\S_{p}<0.001$ compared with control group. $L=$ Live; $A=$ Apoptosis; $N=$ Necrosis. 


\section{Rat lung epithelial cells (L2)}
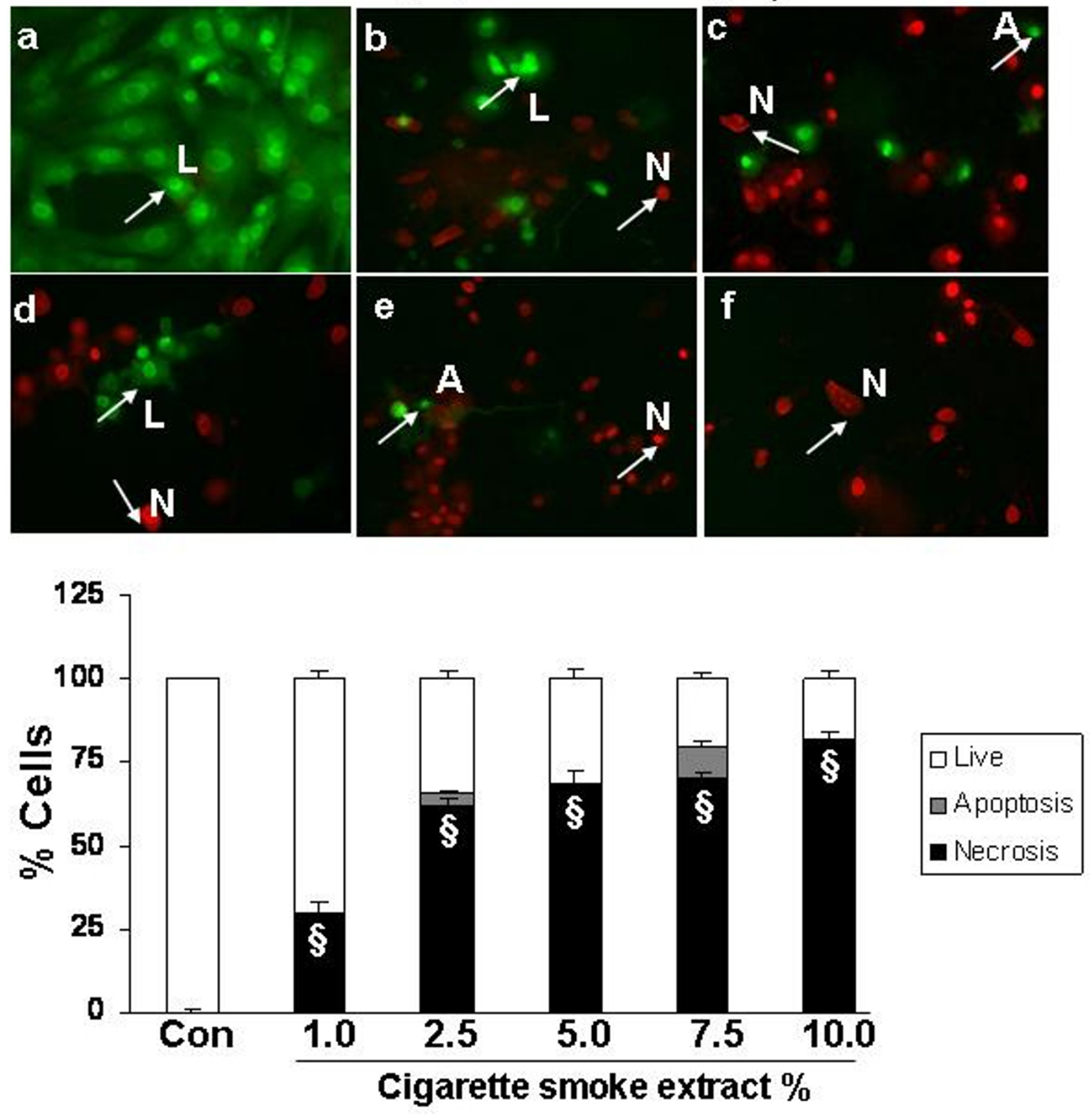

Figure 5

Cigarette smoke extract caused necrosis with no or little evidence of apoptosis in rat lung epithelial cells (L2). Rat lung epithelial cells (L2) were treated with media alone (control) and various concentrations of CSE; a) control, b) CSE

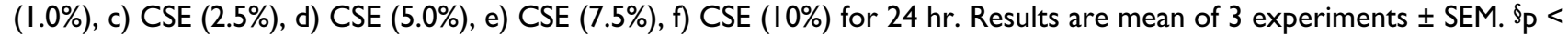
0.00 I compared with control group. $L=$ Live; $A=$ Apoptosis; $N=$ Necrosis. 


\section{Murine type II epithelial cells (MLE-15)}
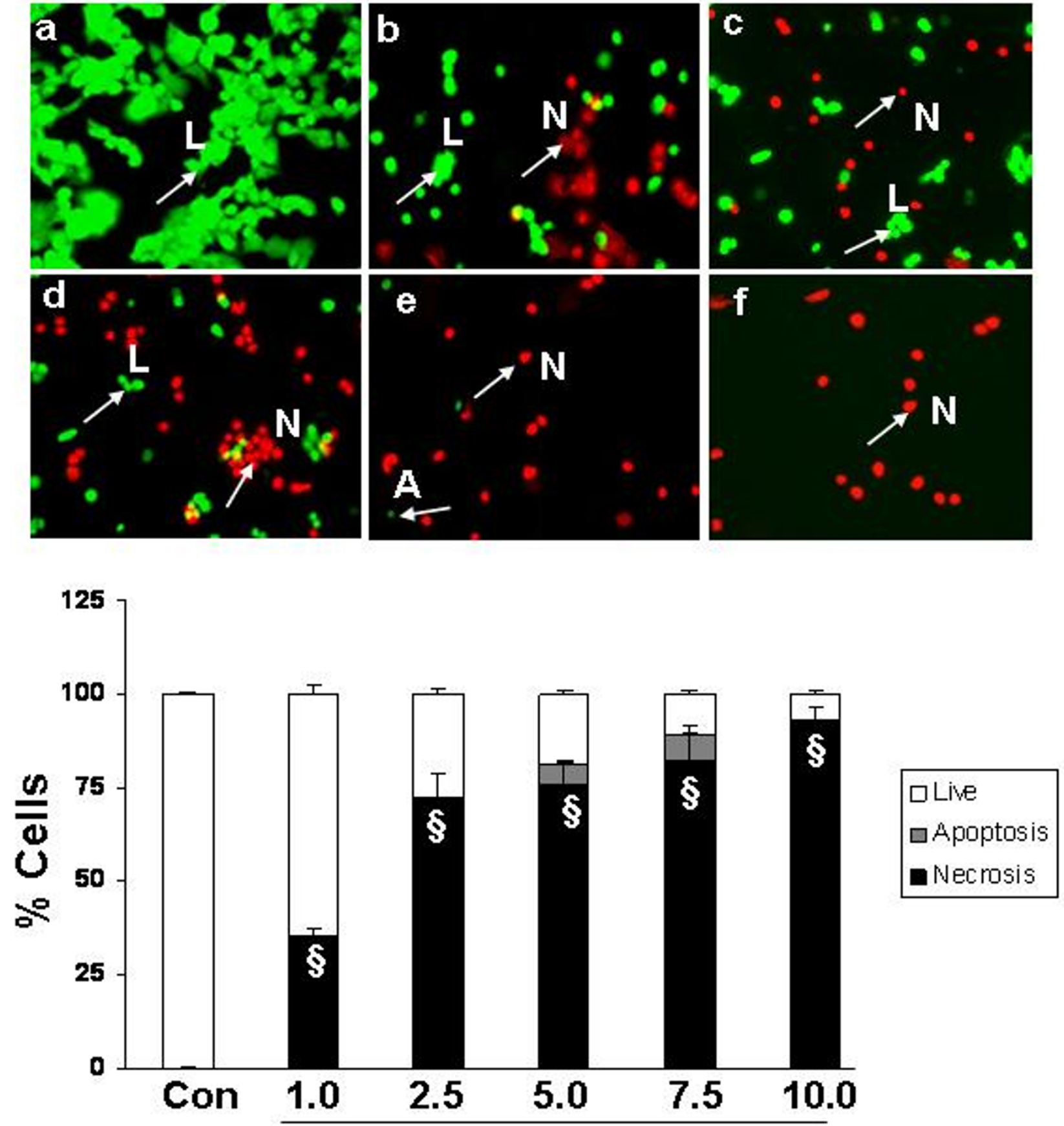

\section{Cigarette smoke extract \%}

\section{Figure 6}

Cigarette smoke extract caused necrosis with no or little evidence of apoptosis in murine type II epithelial cells (MLE-15). Murine type II epithelial cells (MLE- I5) were treated with media alone (control) and various concentrations of CSE; a) control, b) CSE (I.0\%), c) CSE (2.5\%), d) CSE (5.0\%), e) CSE (7.5\%), f) CSE (I0\%) for $24 \mathrm{hr}$. Results are mean of 3 experiments \pm SEM. $\S_{p}<0.00$ I compared with control group $L=$ Live; $A=$ Apoptosis; $N=$ Necrosis. 


\section{Primary human small airway epithelial cells (SAEC)}
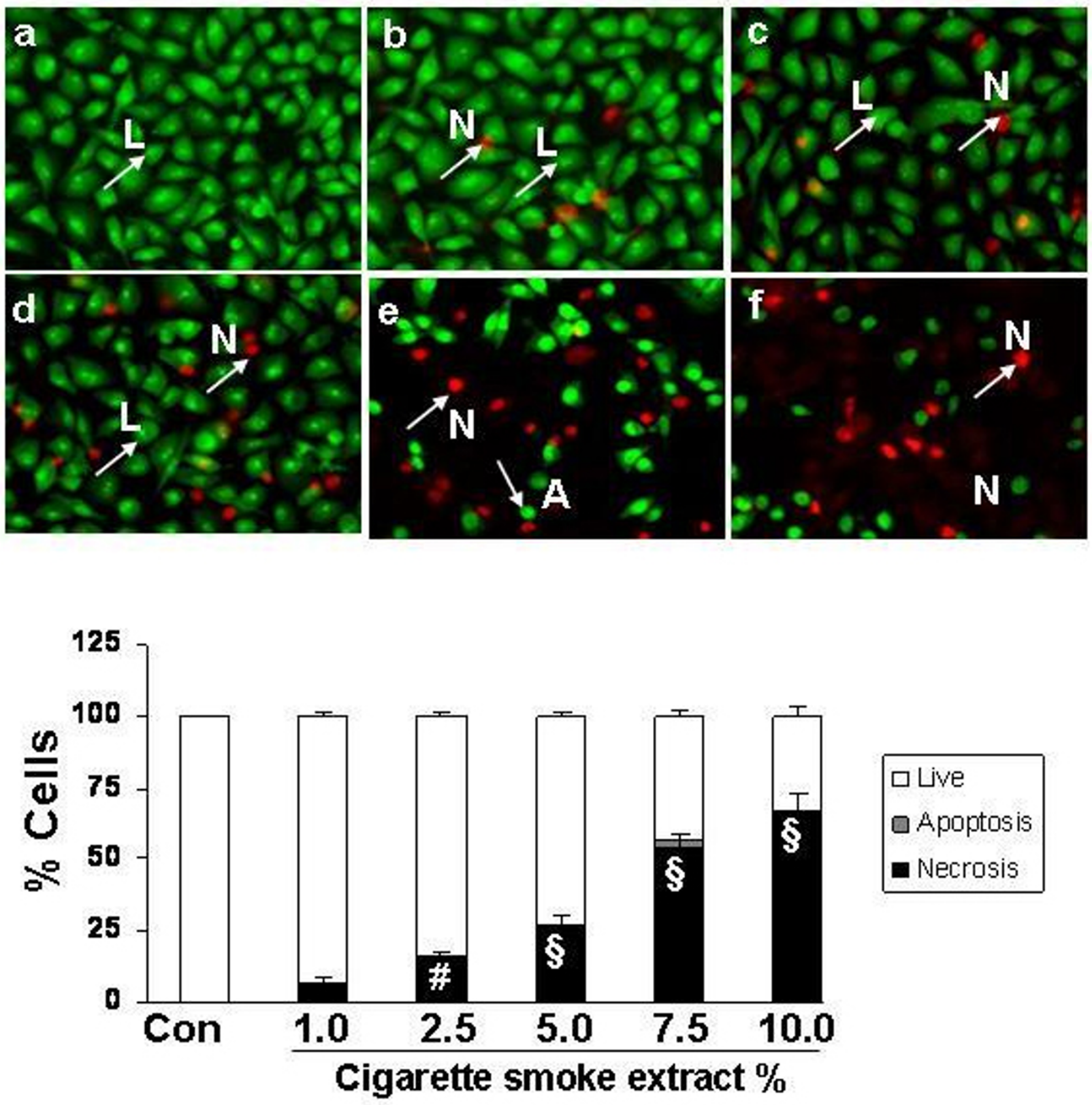

Figure 7

Cigarette smoke extract caused necrosis with no or little evidence of apoptosis in primary human small airway epithelial cells (SAEC). Primary human small airway epithelial cells (SAEC) were treated with media alone (control) and various concentrations of CSE; a) control, b) CSE (0.2\%), c) CSE (0.5\%), d) CSE (I.0\%), e) CSE (2.5\%), f) CSE (5.0\%) for $24 \mathrm{hr}$. Results are mean of 3 experiments \pm SEM. $\# p<0.01$, and $\S_{p}<0.001$ compared with control group. $L=$ Live; $A=$ Apoptosis; $N$ $=$ Necrosis. 

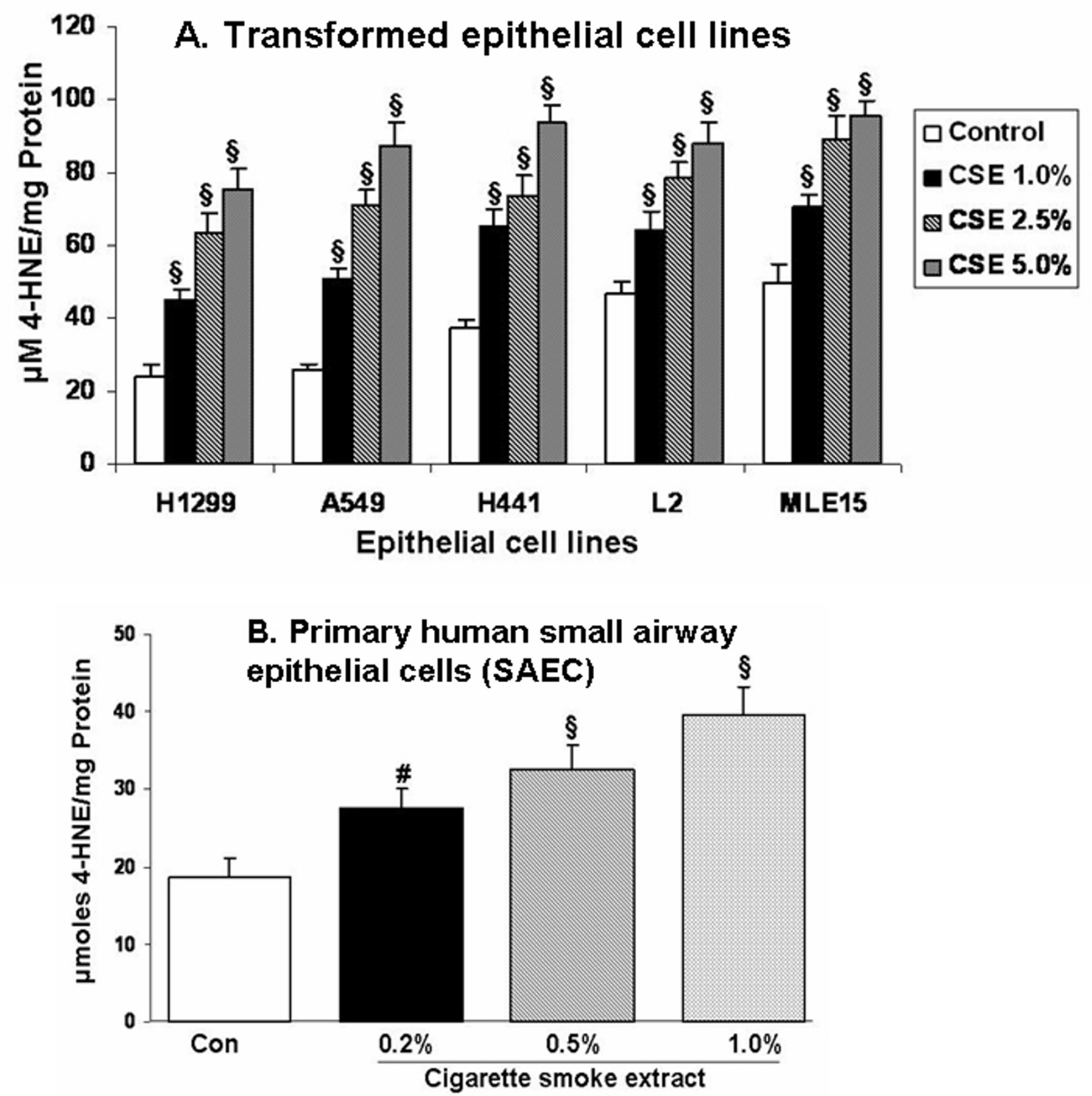

Figure 8

Cigarette smoke extract dose-dependently caused lipid peroxidation measured as 4-hydroxy-2-nonenal levels in alveolar epithelial cells as well as in primary human small airway epithelial cells. A. Transformed alveolar epithelial cells were exposed to cigarette smoke (IR3F) extract (I.0-5.0\%) for $24 \mathrm{hr}$ and the extent of lipid peroxidation was determined by measuring 4-HNE levels. Cigarette smoke extract increased the levels of 4-HNE in all the five transformed alveolar epithelial cell lines in dose-dependent manner. However, the baseline levels of 4-HNE were varied amongst the cell lines, HI299 with lower base line levels and MLE-I 5 with higher baseline levels. B. Primary human small airway epithelial cells (SAEC) were exposed to cigarette smoke extract $(0.2 \%-1.0 \%)$ derived from IR3F research grade cigarettes for $24 \mathrm{hr}$, and the levels of 4-HNE were measured. Cigarette smoke extract dose-dependently increased the levels of 4-HNE levels SAEC. Data represent mean \pm SEM of 3 individual experiments. ${ }^{\S} \mathrm{P}<0.00$ I compared to control values. CSE: cigarette smoke extract. 

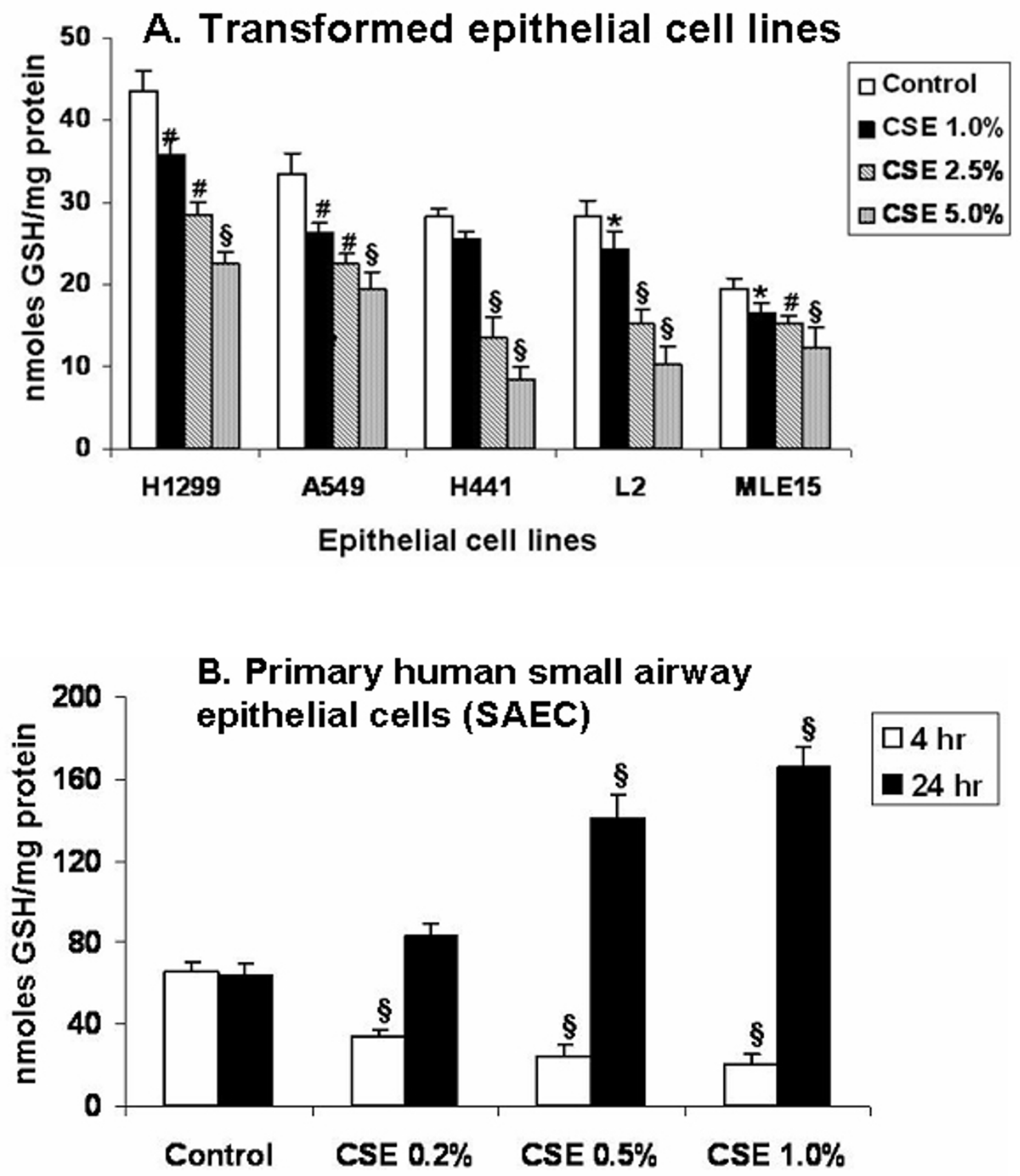

Figure 9

Cigarette smoke extract showed differential effects on intracellular reduced glutathione levels in alveolar epithelial cells and in primary human small airway epithelial cells. A. Transformed alveolar epithelial cell lines of our interest; HI299, A549, H44I, L2 and MLE-I 5 were treated with cigarette smoke extract (I.0-5.0\%) for 24 hr. After incubation period, GSH levels were measured by the Tietze method. Although, the baseline GSH levels were varied amongst the cell lines, CSE decreased GSH levels dose-dependently at $24 \mathrm{hr}$ in all five epithelial cell lines. The most resistant cell line HI299 had higher baseline GSH levels whereas the least resistant MLE-I 5 had lower baseline GSH levels. B. Primary human small airway epithelial cells (SAEC) were also treated with cigarette smoke extract (0.2-1.0\%) for 4 and 24 hrs, and GSH levels were measured. CSE dose- dependently decreased GSH levels in SAEC at $4 \mathrm{hr}$, where as the levels were increased dose-dependently at $24 \mathrm{hr}$. Data is representative of 3 separate experiments \pm SEM. ${ }^{*} p<0.05$, ${ }^{*} p<0.0$ I, and $\S_{p}<0.00$ I compared with corresponding control. CSE: cigarette smoke extract. 
Table I: Cigarette smoke extract did not cause proinflammatory cytokine (IL-8 and IL-6) release in transformed alveolar epithelial cells

\begin{tabular}{|c|c|c|c|c|c|}
\hline \multirow[t]{2}{*}{ Cell line } & \multicolumn{5}{|c|}{ Treatment } \\
\hline & Control & CSE (1.0\%) & CSE (2.5\%) & CSE (5.0\%) & TNF- $\alpha(10 \mathrm{ng} / \mathrm{ml})$ \\
\hline & \multicolumn{5}{|c|}{ Interleukin-8 (IL-8) pg/ml } \\
\hline Human lung cancer cells (HI299) & $51.3 \pm 3.2$ & $53.7 \pm 4.7$ & $56.5 \pm 7.4$ & $45.1 \pm 3.1$ & $432 \pm 59.1 * * *$ \\
\hline Human adenocarcinoma cells (A549) & $623 \pm 52.9$ & $635 \pm 52.4$ & $620 \pm 80.1$ & $612 \pm 76.3$ & $1200 \pm 100 * * *$ \\
\hline \multirow[t]{2}{*}{ Human papillary adenocarcinoma cells $(\mathrm{H} 44 \mathrm{I})$} & $200 \pm 27.2$ & $210 \pm 35.1$ & $200 \pm 58.4$ & $198 \pm 39.2$ & $384 \pm 28.1 * * *$ \\
\hline & \multicolumn{5}{|c|}{ Interleukin-6 (IL-6) pg/ml } \\
\hline Rat lung epithelial cells (L2) & $40.2 \pm 4.8$ & $43.1 \pm 5.2$ & $41.5 \pm 7.2$ & $38.8 \pm 2.6$ & $165 \pm 14.5^{* * *}$ \\
\hline Murine type II epithelial cells (MLE-I5) & $35.6 \pm 2.3$ & $31.4 \pm 5.5$ & $38.1 \pm 2.3$ & $31.9 \pm 3.6$ & $74.5 \pm 5.7^{* * *}$ \\
\hline
\end{tabular}

Alveolar epithelial cell lines (HI299, A549, H44I, L2 and MLE-15) were treated for $24 \mathrm{hr}$ with cigarette smoke extract (I.0-5.0\%) prepared from IR3F research grade cigarettes and TNF- $\alpha$ was used as a positive control $(10 \mathrm{ng} / \mathrm{ml})$. Cells were harvested, and supernatants were collected for the measurement of IL-8 and IL-6 levels by sandwich ELISA. Cigarette smoke extract treatment did not show any significant change in IL-8 and IL-6 release in any of the transformed cell lines, whereas TNF- $\alpha$ treatment induced proinflammatory cytokine (IL-8 and IL-6) release. Data represent mean \pm SEM of 3 individual experiments. $*^{* * *} p<0.001$ compared to control values. CSE: cigarette smoke extract.

\section{Effect of cigarette smoke extract on NF- KB translocation in primary human small airway epithelial cells}

The expression of pro-inflammatory cytokines such as IL8 and IL- 6 are mediated by activation of the redox sensitive transcription factor, NF- $\mathrm{KB}$. Previously, we have shown that CSE had no effect on activation of NF-kB in A549 cells [9]. In this study, we determined whether CSE can cause NF-kB translocation in SAEC since these cells showed a significant increase in proinflammatory cytokine (IL-8) release in response to CSE. Human SAEC showed significant degree of nuclear translocation of NF$\mathrm{KB}$ in response to CSE at 20 min treatment (Figure 10).

Cigarette smoke extract treatment increased NF- $\mathrm{B}$ RelAI p65 levels in the nucleus of primary human small airway epithelial cells

In order to confirm CSE induced nuclear translocation of $\mathrm{NF}-\mathrm{KB}$ in SAEC, nuclear proteins from SAEC treated with CSE were analyzed by western blotting. Cigarette smoke extract (CSE 0.5 and 1.0\%) dose-dependently increased the levels of nuclear NF- $\kappa B$ RelA/p65 in SAEC after $1 \mathrm{hr}$ treatment (Figures 11A and 11B).

\section{Discussion}

Oxidative stress and inflammatory events, in response to cigarette smoke, play an important role in airway and alveolar epithelium injury $[3,4,22]$. In the present study, we investigated the effect of CSE on cytotoxicity, oxidative stress as well as pro-inflammatory cytokine release in a variety of alveolar epithelial cells (A549, H1299, H441, MLE-15 and L2), and compared the effect with primary human SAEC. CSE differentially induced cytotoxicity in various epithelial cell lines in a dose-dependent manner. Among the cell lines studied, rodent lung epithelial cell lines (MLE-15 and L2) were found to be more sensitive to CSE when compared to human lung epithelial cell lines (H1299, A549 and H441). This finding is supported by earlier studies showing that exposure of rat lung epithelial cells to lower concentrations of CSE resulted in a significant decrease in cell viability $[7,9,23]$. Our results also showed that human SAEC were highly sensitive to CSE compared with transformed epithelial cell lines. We postulate that the CSE induced cytotoxic effects may be due the presence of highly reactive electrophilic compounds (aldehydes and quinones) present in CSE $[1,7,24]$, or the

Table 2: Cigarette smoke extract dose-dependently caused induction of proinflammatory cytokine (IL-8 and IL-6) release from primary human small airway epithelial cells

\begin{tabular}{lccccc}
\hline Proinflammatory cytokine $(\mathrm{pg} / \mathrm{ml})$ & \multicolumn{3}{c}{ Treatment } \\
\cline { 2 - 6 } & Control & CSE (0.2\%) & CSE (0.5\%) & CSE (I.0\%) & TNF- $\alpha(10$ ng/mI) \\
\hline Interleukin-8 (IL-8) & $56.2 \pm 7.1$ & $126 \pm 40.6^{* * * *}$ & $171 \pm 21.8^{* * *}$ & $418 \pm 52.3^{* * *}$ & $59 \pm \pm 76.2^{* * * *}$ \\
Interleukin-6 (IL-6) & $87.3 \pm 7.2$ & $187 \pm 43.5^{* * *}$ & $275 \pm 31.6^{* * *}$ & $476 \pm 54.8^{* * *}$ & $623 \pm 51.7^{* * *}$
\end{tabular}

Primary human small airway epithelial cells (SAEC) were treated for $24 \mathrm{hr}$ with cigarette smoke extract $(0.2-1.0 \%)$ prepared from IR3F research grade cigarettes and TNF- $\alpha$ was used as a positive control $(10 \mathrm{ng} / \mathrm{ml})$. Cells were harvested, and supernatants were collected for the measurement of IL-8 and IL-6 levels by sandwich ELISA. CSE treatment dose-dependently induced the release of both IL-8 and IL-6 from human SAEC. Data represent mean \pm SEM of 3 individual experiments. ${ }^{* * *} \mathrm{p}<0.001$ compared to control values. CSE: cigarette smoke extract. 


\section{NF-kB nuclear translocation in primary human small airway epithelial cells (SAEC)}
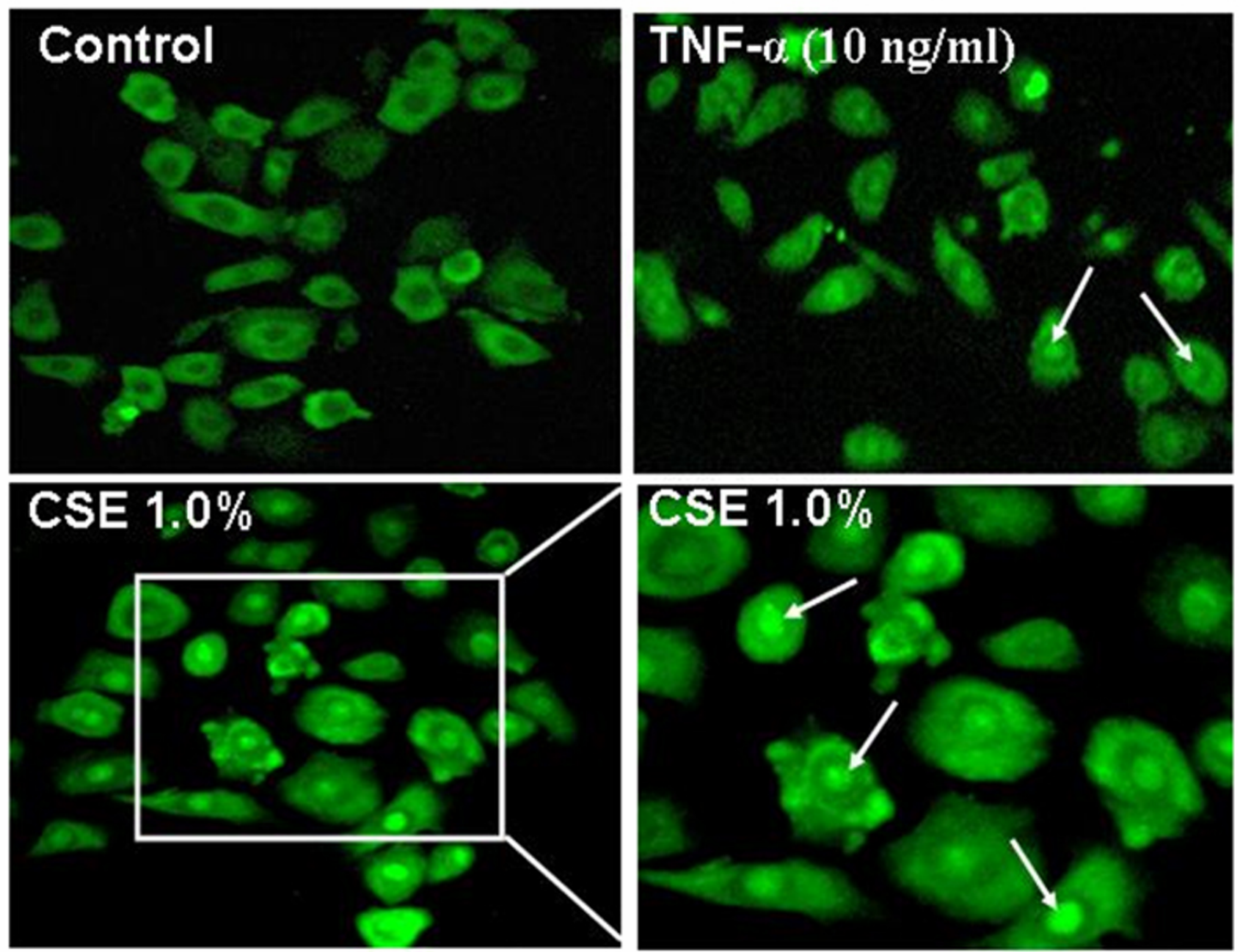

\section{Figure 10}

Cigarette smoke extract treatment caused NF- $\mathrm{B}$ RelA/p65 nuclear translocation in primary human small airway epithelial cells. Primary human small airway epithelial cells were grown in 8-well chamber slides and were exposed for 20 min. to CSE (I.0\%) prepared from IR3F research grade cigarettes. TNF- $\alpha(10 \mathrm{ng} / \mathrm{ml})$ was used as a positive. After treatment period, the cells were incubated with NF-KB RelA/p65 antibody and were visualized under fluorescent microscope. Cigarette smoke extract and TNF- $\alpha$ treatments caused nuclear translocation of NF- $\kappa B$ RelA/p65.

generation of intracellular ROS. Indeed, previous studies have shown that the cytotoxic ability of cigarette smoke $[7,22,25-27]$ is due to a number of chemical components of cigarette smoke such as acrolein, nicotine, benzo(a)pyrene, and N- nitrosamines [28-30]. Nevertheless, our data clearly show that CSE caused toxicity to alveolar epithelial cells, which may contribute to the development of lung diseases induced by cigarette smoking $[4,22,28]$.
Apoptosis is a well-defined programmed response that results in characteristic morphologic changes, such as cell shrinkage, condensation and fragmentation of nuclear material. Necrosis on the other hand, is a passive response characterized by cytoplasmic swelling, rapid loss of plasma membrane integrity, and eventually cell lysis [31]. We therefore studied the effect of CSE on cell death in various epithelial cells. Our data showed that CSE induced necrosis in a dose-dependent manner in all the five trans- 


\section{A. Primary human small airway epithelial cells (SAEC)}
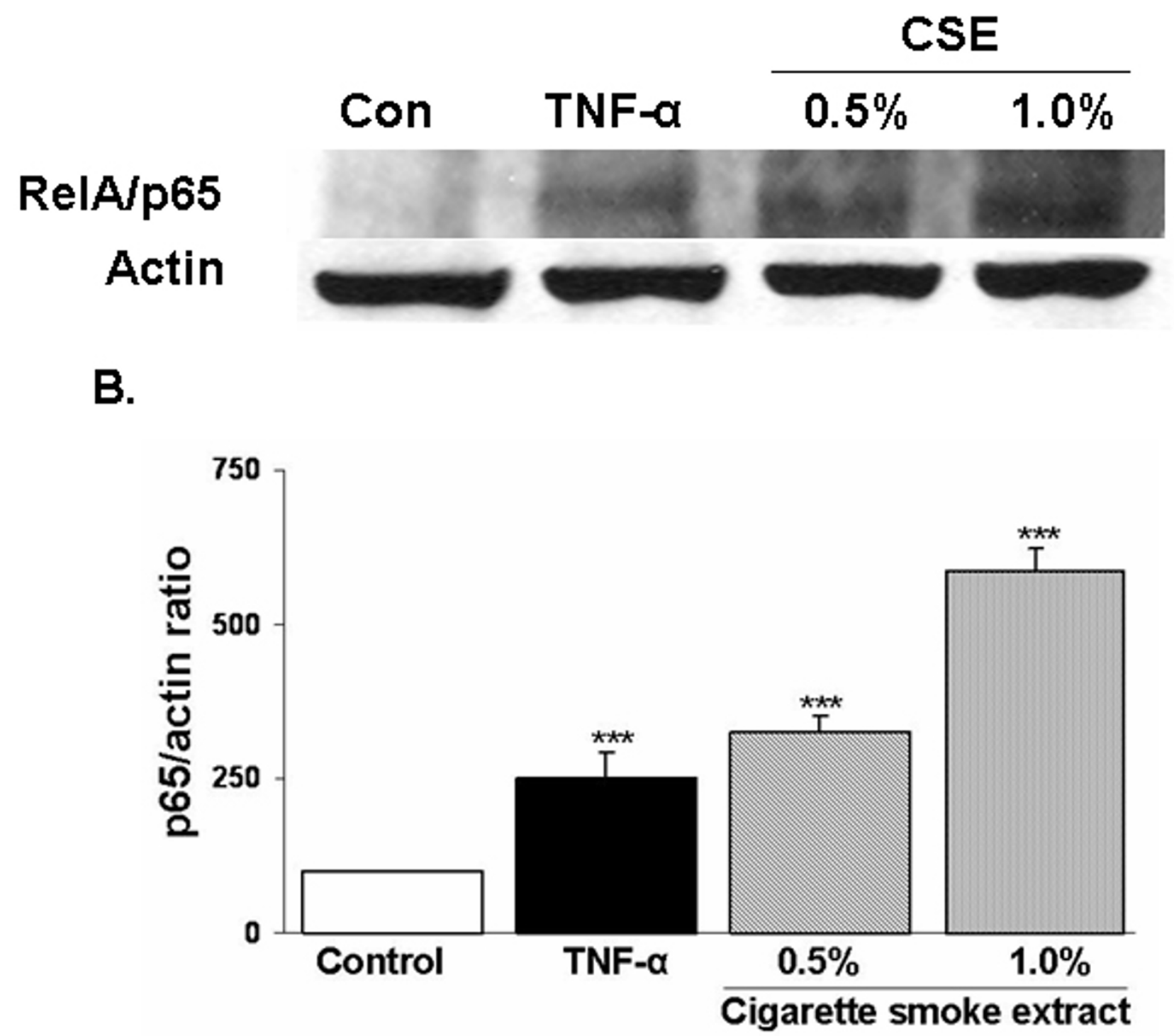

Figure I I

Cigarette smoke extract mediated nuclear translocation of NF-KB RelA/p65 was associated with increased nuclear levels of NF- $\kappa B$ RelA/p65 protein in human primary small airway epithelial cells. The primary human SAEC were treated with CSE (0.5 and $1.0 \%)$, and TNF- $\alpha(10 \mathrm{ng} / \mathrm{ml})$ for I $\mathrm{hr}$ and nuclear proteins were isolated. Twenty microgram of nuclear protein was electrophoresed on SDS-PAGE and electroblotted onto membranes. A). Western blot showing increased nuclear levels of RelA/p65 in CSE and TNF- $\alpha$ treated SAEC at I hr. B). Nuclear protein levels of NF- $\mathrm{kB}$ p65 were expressed as the percentage of ratio of RelA/p65 versus actin in human SAEC. Each histogram is a representative of 3 separate experiments \pm SEM. ${ }^{*} p<0.05$, ${ }_{p} p<0.01$, and $\S_{p}<0.001$ compared with control. CSE: cigarette smoke extract.

formed epithelial cell lines as well as in SAEC. However, there was a significant variability in their sensitivity to different doses of CSE. Our data showing cigarette smoke induced necrosis with no or little evidence of apoptosis is in contrast to previous studies in macrophages and endothelial cells [26,32], where CSE was shown to induce apoptosis, but is in agreement with the earlier studies by Wickenden et al [17] who showed that cigarette smoke exposure inhibited apoptosis by preventing caspase activation, and instead promoted necrosis in alveolar epithe- 
lial (A549) cells. Furthermore, it is possible that the mode of cell death may be dependent on the cell type and the concentration of stimulus employed [33].

An imbalance between oxidants and antioxidants has been shown to occur in smokers $[4,7,22]$ resulting in tissue injury. Such tissue damaging effects could be attributed to the presence of $10^{14}-10^{16}$ oxidantmolecules/puff of cigarette smoke [1]. 4-hydroxy-2- nonenal, a highly reactive and diffusible end product of lipid peroxidation, is a known marker of oxidative stress and can attack target cells far from the site of the original free radical event [3436]. It is a potent alkylating agent, which reacts with DNA and proteins, generating various types of adducts $[34,36,37]$ that are capable of inducing stress signaling pathways and apoptosis [37]. It is possible that 4-HNE is generated by CSE either directly or indirectly via lipid peroxidation of cell membranes. In this study, we have attempted to study whether any variations in the extent of lipid peroxidation induced by CSE in various epithelial cells is responsible for differential cytotoxicity. Indeed, our data showed that cigarette smoke extract dosedependently caused increase in oxidative stress in all five cell lines and the baseline levels of 4-HNE were varied amongst the cell lines based on their sensitivity to CSE as observed for cytotoxicity. Furthermore, CSE dose-dependently increased the levels of 4-HNE in SAEC. This observation is corroborated with our previous findings that the levels of 4-HNE were increased in airways and alveolar epithelium of smokers and COPD subjects [38].

Glutathione (GSH) is a major intra- and extracellular antioxidant in the lung. We studied the effect of CSE on intracellular GSH levels in a variety of transformed epithelial cell lines and SAEC, since CSE has been shown to induce oxidative stress and alter glutathione homeostasis. Consistent to our hypothesis, we were able to show that treatment with CSE resulted in significant depletion of GSH levels in all the five epithelial cell lines without any significant change in GSSG levels (data not shown). It is possible that CSE mediated depletion of GSH levels could be due to the formation of GSH conjugates with electrophilic $\beta$-carbonyl compounds present in cigarette smoke as shown previously [8]. Moreover, our observation is consistent with earlier findings of the ability of cigarette smoke to induce oxidative stress by generation of reactive oxygen species and decrease intracellular GSH levels (without an increased levels of GSSG) in alveolar type II cells $[8,20]$. Interestingly, we observed differences in baseline GSH levels amongst the five epithelial cell lines studied. This potentially reflects the endogenous ability of the cells to adapt to cigarette smoke mediated injury and damage, which may in turn be attributed to the original intracellular concentration of GSH. However, this contention needs further experimentation. Another important finding was that CSE decreased GSH levels dose-dependently in SAEC at $4 \mathrm{hr}$ time period. However, the levels were increased dose-dependently at $24 \mathrm{hr}$ time period, which may be due to the rebound effect as a compensatory mechanism by up-regulation of glutamate cysteine ligase (glutathione biosynthesis) [39]. Overall, our findings on oxidant and antioxidant parameters suggest that CSE-induced cytotoxicity in different cell lines is due the base-line or endogenous levels of glutathione status and the amount of 4-HNE is formed.

IL- 8 and IL- 6 are important in the recruitment and activation of inflammatory cells. The induction of these proinflammatory mediators is regulated by the activation of redox sensitive transcription factor NF- $\mathrm{KB}[40,15]$. This transcription factor has been shown to be activated by a wide variety of agents including stress, cigarette smoke, viruses, bacteria, inflammatory stimuli, cytokines and free radicals [40-43]. Previously we and others have shown that CSE caused activation of NF- $\kappa \mathrm{B}$ and pro-inflammatory cytokines release in human monocytic cell line (MM6), Swiss 3T3, human histolytic lymphoma (U-937) and Jurkat $\mathrm{T}$ cells $[13,44,45]$. However, in another study by Moodie et al. CSE had no effect on either activation of NF- $\kappa \mathrm{B}$ or pro-inflammatory cytokine release in A549 cells [9]. Hence, we investigated whether or not any other alveolar epithelial cell lines produce pro-inflammatory cytokines in response to CSE, which could potentially be used as a model to understand the mechanism of cigarette smoke-induced inflammatory events. We therefore, studied the effect of CSE on NF-KB activation in SAEC, and proinflammatory cytokine release in a variety of epithelial cell lines. Our data showed no effect of CSE on the release of pro-inflammatory mediators in any of the transformed alveolar epithelial cells studied. This observation is in agreement with our previous observation in A549 cells where CSE did not show activation of NF- $\mathrm{KB}$ and proinflammatory cytokine release [9]. Bihl et al have also showed that transformed human alveolar epithelial cells such as H1299 lack IL-6 production [46]. The reason for lack of pro-inflammatory effect of cigarette smoke in these cell lines is still unclear but it may be possible that the transformed epithelial cells have altered intracellular NF$\kappa \mathrm{B}$ and MAP kinase signaling mechanisms compared to normal cells. Interestingly, CSE induced both IL-8 and IL6 release with a corresponding increase in nuclear translocation of RelA/p65 in SAEC as shown by immunofluorescent staining. Furthermore, western blot analysis of NF- $\mathrm{KB}$ RelA/p65 revealed increased levels of RelA/p65 in CSE treated SAEC cells compared with untreated SAEC. It is possible that apart from RelA/p65 (NF- $\mathrm{KB})$, other transcription factors (such as AP-1, NF-IL6) may be responsible for CSE induced pro-inflammatory cytokine release. Our findings in SAEC gain credence from previous studies in human subjects wherein an increased expression of NF- 
$\kappa \mathrm{B}$ was reported in the airway epithelium of smokers compared to nonsmokers [47]. Furthermore, increased levels of chemokines were also reported in alveolar type II cells obtained from smokers [48]. However, further investigations are required to understand the molecular signaling pathways involved in the pro-inflammatory effects of cigarette smoke in primary human airway epithelial cells

In conclusion, our data showed that CSE caused oxidative stress in a variety of alveolar epithelial cell lines as well as in primary human small airway epithelial cells. However, CSE triggered NF- $\kappa \mathrm{B}$ activation and pro-inflammatory cytokine release in primary human small airway epithelial cells but not in any of the transformed epithelial cell lines studied. This study suggests that primary, but not transformed, lung epithelial cells are an appropriate model to study the inflammatory mechanisms in response to cigarette smoke in in vitro system.

\section{Abbreviations}

CSE: Cigarette smoke extract

ELISA: Enzyme linked immunosorbent assay

FBS: Fetal bovine serum

GSH: Reduced glutathione

4-HNE: 4-Hydroxy-2-nonenal

IL-6: Interleukin-6

IL-8: Interleukin-8

LDH: Lactate dehydrogenase

NF-кB: Nuclear Factor kappa B

PBS: Phosphate buffered saline

SAEC: Small airway epithelial cells

TNF- $\alpha$ : Tumor necrosis factor-alpha

\section{Competing interests}

The author(s) declare that they have no competing interests.

\section{Authors' contributions}

AK performed all studies mentioned and drafted the manuscript. SY assisted with immunocytochemistry study. IR was involved in the design, supervision and writing of the manuscript. All authors read and approved the final manuscript.

\section{Acknowledgements}

This study was supported by the NIEHS Environmental Health Sciences Center Support (ESO 247). The authors thank Drs. Michael A. O'Reilly, Patricia R. Chess and Jacob N. Finkelstein for providing various alveolar epithelial cell lines. We thank Dr. Saibal K. Biswas for his useful corrections during the revision of this manuscript.

\section{References}

I. Pryor WA, Stone K: Oxidants in cigarette smoke. Radicals, hydrogen peroxide, peroxynitrate, and peroxynitrite. Ann NY Acad Sci 1993, 686: 12-27.

2. Church DF, Pryor WA: Free-radical chemistry of cigarette smoke and its toxicological implications. Environ Health Perspect 1985, 64: III-I26.

3. Kirkham P, Rahman I: Oxidative stress in asthma and COPD: Antioxidants as a therapeutic strategy. Pharmacol Ther 2006, I I I:476-494.

4. Rahman I, Biswas SK, Kode A: Oxidant and antioxidant balance in the airways and airway diseases. Eur J Pharmacol 2006, 533:222-239.

5. Marwick JA, Kirkham PA, Stevenson CS, Danahay H, Giddings J, Butler K, Donaldson K, MacNee W, Rahman I: Cigarette smoke alters chromatin remodeling and induces proinflammatory genes in rat lungs. Am J Respir Cell Mol Biol 2004, 31:633-642.

6. Vlahos R, Bozinovski S, Jones JE, Powell J, Gras J, Lilja A, Hansen MJ, Gualano RC, Irving L, Anderson GP: Differential protease, innate immunity and NF\{kappa\}B induction profiles during lung inflammation induced by sub-chronic cigarette smoke exposure in mice. Am J Physiol 2005, 290:L93I-L945.

7. Lannan S, Donaldson K, Brown D, MacNee W: Effect of cigarette smoke and its condensates on alveolar epithelial cell injury in vitro. Am J Physiol 1994, 266:L92-LI00.

8. Rahman I, Li XY, Donaldson K, Harrison DJ, MacNee W: Glutathione homeostasis in alveolar epithelial cells in vitro and lung in vivo under oxidative stress. Am J Physiol 1995, 269:L285-L292.

9. Moodie FM, Marwick JA, Anderson CS, Szulakowski P, Biswas SK, Bauter MR, Kilty I, Rahman I: Oxidative stress and cigarette smoke alter chromatin remodeling but differentially regulate NF- $\kappa$ B activation and proinflammatory cytokine release in alveolar epithelial cells. FASEB J 2004, I 8: I 897-1899.

10. Shapiro SD: Smoke gets in your cells. Am J Respir Cell Mol Biol 2004, 31:48I-482.

II. Ikeda K, Clark JC, Bachurski CJ, Wikenheiser KA, Cuppoletti J, Mohanti S, Morris RE, Whitsett JA: Immortalization of subpopulations of respiratory epithelial cells from transgenic mice bearing SV40 large T antigen. Am JPhysiol 1994, 267:L309-L3 I7.

12. Wikenheiser KA, Vorbroker DK, Rice WR, Clark JC, Bachurski CJ, Oie HK, Whitsett JA: Production of immortalized distal respiratory epithelial cell lines from surfactant protein $\mathrm{C} /$ simian virus $\mathbf{4 0}$ large tumor antigen transgenic mice. Proc Natl Acad Sci USA 1993, 90: I 1029-11033.

13. Yang SR, Chida AS, Bauter M, Shafiq N, Seweryniak K, Maggirwar SB, Kilty I, Rahman I: Cigarette smoke induces proinflammatory cytokine release by activation of NF-KB and post-translational modifications of histone deacetylase in in macrophages. Am J Physiol 2006, 29 I:L46-L57.

14. Carp H, Janoff A: Possible mechanisms of emphysema in smokers. In vitro suppression of serum elastase-inhibitory capacity by fresh cigarette smoke and its prevention by antioxidants. Am Rev Respir Dis 1978, I I 8:617-62I.

15. Rahman I, Gilmour PS, Jimenez LA, Biswas SK, Antonicelli F, Aruoma OI: Ergothioneine inhibits oxidative stress- and TNF-alphainduced NF-kappa B activation and interleukin-8 release in alveolar epithelial cells. Biochem Biophys Res Commun 2003, 302:860-864.

16. Martin D, Leonardo M: Microscopic quantitation of apoptotic index and cell viability using vital and fluorescent dyes. In Current Protocols in Immunology Edited by: Coligan JE, Kruisbeek AM, Margulies D, Shevach EM, Strober W. New York: John Wiley \& Sons; 1994:3.17.I-3.17.39.

17. Wickenden JA, Clarke MC, Rossi AG, Rahman I, Faux SP, Donaldson $\mathrm{K}$, MacNee W: Cigarette smoke prevents apoptosis through inhibition of caspase activation and induces necrosis. Am J Respir Cell Mol Biol 2003, 29:562-570. 
18. Tietze F: Enzymic method for quantitative determination of nanogram amounts of total and oxidized glutathione: applications to mammalian blood and other tissues. Anal Biochem 1969, 27:502-522

19. Rahman I, Antonicelli F, MacNee W: Molecular mechanism of the regulation of glutathione synthesis by tumor necrosis factor$\alpha$ and dexamethasone in human alveolar epithelial cells. J Biol Chem 1999, 274:5088-5096.

20. Rahman I, Mulier B, Gilmour PS, Watchorn T, Donaldson K, Jeffery PK, MacNee W: Oxidant-mediated lung epithelial cell tolerance: the role of intracellular glutathione and nuclear factorkappaB. Biochem Pharmacol 2001, 62:787-794.

21. Yang SR, Wright J, Bauter M, Seweryniak K, Kode A, Rahman I: Sirtuin regulates smoke induced proinflammatory mediators release via acetylation of RelA/p65 NF-KB in macrophages in vitro and in rat lungs in vivo. Am J Physiol Lung Cell and Mol Physiol 2006. (Epubmed)

22. Rahman I, MacNee W: Lung glutathione and oxidative stress: implications in cigarette smoke-induced airway disease. Am J Physiol 1999, 277:LI 067-LI088.

23. Onoue S, Endo K, Ohmori Y, Yamada S, Kimura R, Yajima T, Kashimoto $\mathrm{K}$ : Long-acting analogue of vasoactive intestinal peptide, [RI5, 20, 2I, LI7]-VIP-GRR (IK3 I 2532), protects rat alveolar L2 cells from the cytotoxicity of cigarette smoke. Regul Pept 2004, I 23:193-199.

24. Pouli AE, Hatzinikolaou DG, Piperi C, Stavridou A, Psallidopoulos MC, Stavrides JC: The cytotoxic effect of volatile organic compounds of the gas phase of cigarette smoke on lung epithelial cells. Free Radic Biol Med 2003, 34:345-355.

25. Aoshiba K, Tamaoki J, Nagai A: Acute cigarette smoke exposure induces apoptosis of alveolar macrophages. Am J Physiol 200I, 28I:LI392-LI40I.

26. Hoshino Y, Mio T, Nagai S, Miki H, Ito I, Izumi T: Cytotoxic effects of cigarette smoke extract on an alveolar type II cell-derived cell line. Am J Physiol 200I, 28I:L509-L5I6.

27. Wang J, Wilcken DEL, Wang XL: Cigarette smoke activates caspase-3 to induce apoptosis of human umbilical venous endothelial cells. Mol Genet Metab 200I, 72:82-88.

28. Brunnemann KD, Prokopczyk B, Djordjevic MV, Hoffmann D: Formation and analysis of tobacco-specific $\mathbf{N}$-nitrosamines. Crit Rev Toxicol 1996, 26:121-37.

29. Kehrer JP, Biswal SS: The molecular effects of acrolein. Toxicol Sci 2000, 57:6-15.

30. Wetscher GJ, Bagchi M, Bagchi D, Perdikis G, Hinder PR, Glaser K, Hinder RA: Free radical production in nicotine treated pancreatic tissue. Free Radic Biol Med 1995, 18:877-882.

31. Majno G, Joris I: Apoptosis, oncosis, and necrosis: An overview of cell death. Am J Pathol 1995, I46:3-I5.

32. Tuder RM, Wood K, Taraseviciene L, Flores SC, Voekel NF: Cigarette smoke extract decreases the expression of vascular endothelial growth factor by cultured cells and triggers apoptosis of pulmonary endothelial cells. Chest 2000, I 1 7:241-242.

33. Lennon SV, Martin SJ, Cotter TG: Dose-dependent induction of apoptosis in human tumour cell lines by widely diverging stimuli. Cell Prolif 1991, 24:203-214.

34. Doorn JA, Petersen DR: Covalent modification of amino acid nucleophiles by the lipid peroxidation products 4-hydroxy-2nonenal and 4-oxo-2-nonenal. Chem Res Toxicol 2002, 15:1445-1450.

35. Uchida K, Szweda LI, Chae HZ, Stadtman ER: Immunochemical detection of 4-hydroxynonenal protein adducts in oxidized hepatocytes. Proc Natl Acad Sci USA 1993, 90:8742-8746.

36. Esterbauer H, Schaur RJ, Zollner H: Chemistry and biochemistry of 4-hydroxynonenal, malonaldehyde and related aldehydes. Free Radic Biol Med 1991, I I:81-128.

37. Uchida K, Shiraishi M, Naito Y, Torii Y, Nakamura Y, Osawa T: Activation of stress signaling pathways by the end product of lipid peroxidation. 4-Hydroxy-2-nonenal is a potential inducer of intracellular peroxide production. I Biol Chem 1999, 274:2234-2242.

38. Rahman I, van Schadewijk AA, Crowther AJ, Hiemstra PS, Stolk J, MacNee W, De Boer WI: 4-Hydroxy-2-nonenal, a specific lipid peroxidation product, is elevated in lungs of patients with chronic obstructive pulmonary disease. Am J Respir Crit Care Med 2002, 166:490-495.
39. Rahman I, Smith CA, Lawson MF, Harrison DJ, MacNee W: Induction of gamma-glutamylcysteine synthetase by cigarette smoke is associated with AP-I in human alveolar epithelial cells. FEBS Letts 1996, 396:2I-25.

40. Rahman I, Gilmour PS, Jimenez LA, MacNee W: Oxidative stress and TNF-alpha induce histone acetylation and NF-kappaB/ AP-I activation in alveolar epithelial cells: potential mechanism in gene transcription in lung inflammation. Mol Cell Biochem 2002, 234:239-248.

41. Rahman I, MacNee W: Role of transcription factors in inflammatory lung diseases. Thorax 1998, 53:60I-6I2.

42. Ahn KS, Aggarwal BB: Transcription Factor NF-KB: A Sensor for Smoke and Stress Signals. Ann N Y Acad Sci 2005, 1056:218-233.

43. Anto RJ, Mukhopadhyay A, Shishodia S, Gairola CG, Aggarwal BB Cigarette smoke condensate activates nuclear transcription factor- $K B$ through phosphorylation and degradation of $\operatorname{I\kappa B}(\alpha)$ : correlation with induction of cyclooxygenase-2. Carcinogenesis 2002, 23:151I-1518.

44. Gebel S, Muller T: The activity of NF- $\kappa B$ in Swiss $3 T 3$ cells exposed to aqueous extracts of cigarette smoke is dependent on thioredoxin. Toxicol Sci 200I, 59:75-8I.

45. Jimenez LA, Thompson J, Brown DA, Rahman I, Antonicelli F, Duffin R, Drost EM, Hay RT, Donaldson K, MacNee W: Activation of NF$\kappa B$ by $P_{10}$ occurs via an iron-mediated mechanism in the absence of IKB degradation. Toxicol Appl Pharmacol 2000, 166:101-110

46. Bihl M, Tamm M, Nauck M, Wieland H, Perruchoud AP, Roth M: Proliferation of human non-small-cell lung cancer cell lines: role of interleukin-6. Am J Respir Cell Mol Biol 1998, 19:606-612.

47. Di Stefano A, Caramori G, Oates T, Capelli A, Lusuardi M, Gnemmi I, loli F, Chung KF, Donner CF, Barnes PJ, Adcock IM: Increased expression of nuclear factor- $K B$ in bronchial biopsies from smokers and patients with COPD. Eur Respir J 2002, 20:556-563.

48. Witherden IR, Vanden Bon EJ, Goldstraw P, Ratcliffe C, Pastorino U, Tetley TD: Primary human alveolar type II epithelial cell chemokine release: effects of cigarette smoke and neutrophil elastase. Am J Respir Cell Mol Biol 2004, 30:500-509.

Publish with Bio Med Central and every scientist can read your work free of charge

"BioMed Central will be the most significant development for disseminating the results of biomedical research in our lifetime. "

Sir Paul Nurse, Cancer Research UK

Your research papers will be:

- available free of charge to the entire biomedical community

- peer reviewed and published immediately upon acceptance

- cited in PubMed and archived on PubMed Central

- yours - you keep the copyright

Submit your manuscript here:

http://www.biomedcentral.com/info/publishing_adv.asp
BioMedcentral 